\title{
Strengthening of North American dust sources during the late Pliocene (2.7 Ma)
}

\author{
B. David A. Naafs a,b,*, Jens Hefter a , Gary Acton ${ }^{\text {c }}$, Gerald H. Haug ${ }^{\text {b,d }}$, Alfredo Martínez-Garcia ${ }^{\text {b,d }}$, \\ Richard Pancost ${ }^{\mathrm{e}}$, Ruediger Stein ${ }^{\mathrm{a}}$ \\ a Alfred Wegener Institute for Polar and Marine Research, Department of Marine Geology and Paleontology, D-27568 Bremerhaven, Germany \\ ${ }^{\mathrm{b}}$ Leibniz Center for Earth Surface and Climate Studies, Institute for Geosciences, Potsdam University, D-14476 Potsdam, Germany \\ c Department of Geology, University of California, CA 95616 Davis, USA \\ d Geological Institute, ETH Zürich, 8092 Zürich, Switzerland \\ e Organic Geochemistry Unit, Bristol Biogeochemistry Research Centre, School of Chemistry, University of Bristol, Cantock's Close, BS8 1TS Bristol, United Kingdom
}

\section{A R T I C L E I N F O}

\section{Article history:}

Received 26 May 2011

Received in revised form 29 October 2011

Accepted 21 November 2011

Available online $\mathrm{xxxx}$

Editor: P. DeMenocal

\section{Keywords:}

aeolian input

dust

terrestrial higher plant waxes

Milankovitch

North Atlantic

Quaternary

\begin{abstract}
A B S T R A C T
Here we present orbitally-resolved records of terrestrial higher plant leaf wax input to the North Atlantic over the last 3.5 Ma, based on the accumulation of long-chain $n$-alkanes and $n$-alkanl-1-ols at IODP Site U1313. These lipids are a major component of dust, even in remote ocean areas, and have a predominantly aeolian origin in distal marine sediments. Our results demonstrate that around 2.7 million years ago (Ma), coinciding with the intensification of the Northern Hemisphere glaciation (NHG), the aeolian input of terrestrial material to the North Atlantic increased drastically. Since then, during every glacial the aeolian input of higher plant material was up to 30 times higher than during interglacials. The close correspondence between aeolian input to the North Atlantic and other dust records indicates a globally uniform response of dust sources to Quaternary climate variability, although the amplitude of variation differs among areas. We argue that the increased aeolian input at Site U1313 during glacials is predominantly related to the episodic appearance of continental ice sheets in North America and the associated strengthening of glaciogenic dust sources. Evolutional spectral analyses of the $n$-alkane records were therefore used to determine the dominant astronomical forcing in North American ice sheet advances. These results demonstrate that during the early Pleistocene North American ice sheet dynamics responded predominantly to variations in obliquity (41 ka), which argues against previous suggestions of precession-related variations in Northern Hemisphere ice sheets during the early Pleistocene.
\end{abstract}

(c) 2011 Elsevier B.V. All rights reserved.

\section{Introduction}

Small rock fragments, soil particles, and pollen can easily be entrained by the wind and transported over large distances through the atmosphere (Ridgwell, 2002). This heterogeneous mixture of aerosols, i.e. dust, plays an important role in global climate (Maher et al., 2010) as it influences the radiative forcing of the atmosphere (Mahowald et al., 2006b), and can be a source of nutrients (e.g., iron) to the open ocean that can lead to a strengthening of the biological pump (Fung et al., 2000; Martin, 1990; Mills et al., 2004). In addition, dust particles influence cloud formation by providing cloud condensation nuclei (Mahowald and Kiehl, 2003), and can affect the albedo of ice sheets (Ridgwell, 2002).

Globally distributed climate records show that the global emission of dust was significantly higher during the most recent glacials than during interglacials such as the present (e.g., Maher et al., 2010;

\footnotetext{
* Corresponding author at: Alfred Wegener Institute for Polar and Marine Research, Department of Marine Geology and Paleontology, D-27568 Bremerhaven, Germany. Tel.: + 4947148312120 ; fax: + 4947148311923.

E-mail address: david.naafs@awi.de (B.D.A. Naafs).
}

Mahowald et al., 2011; McGee et al., 2010). For example the analysis of dust particles in ice cores from the Antarctic continent shows that throughout the last $800 \mathrm{ka}$ the dust flux to Antarctica was 25 times higher during glacials than during interglacials (Lambert et al., 2008). Although dust deposition in the low-latitudes was also higher during glacials (deMenocal, 1995; McGee et al., 2010; Tiedemann et al., 1994; Winckler et al., 2008), it was lower than the glacial flux in the higher latitudes of the Southern Hemisphere (Lambert et al., 2008; Martínez-Garcia et al., 2009, 2011). The 5 to 8 times higher dust deposition during glacials in the Southern Ocean (Kumar et al., 1995; Martínez-Garcia et al., 2009, 2011) has been explained by the effect of continental ice sheets in Patagonia that act as an amplifying mechanism for dust emission in the higher latitudes (Ridgwell and Watson, 2002; Sugden et al., 2009; Winckler et al., 2008), while the even greater increase seen in Antarctic dust fluxes is attributed to the additional effect of a more efficient transport mechanism during glacials (Lambert et al., 2008).

Continental ice sheets are effective dust sources as the grinding of rocks by continental ice sheets produces large amounts of glaciogenic dust that is transported by melt waters toward glacial outwash plains where it can easily be entrained by wind (Ganopolski et al., 2010; 
Maher et al., 2010; Mahowald et al., 2006a). The presence of extensive loess deposits between 45 and $35^{\circ} \mathrm{N}$ in the interior of North America (Bettis et al., 2003) indicates that the margins of the North American ice sheets were a major dust source during the last glacial, in-line with modeling results (Ganopolski et al., 2010). Studies using the accumulation of organic biomarkers derived from terrestrial higher plant leaf waxes in marine sediments from the northern North Atlantic, downwind from the North American continent, demonstrate similar results with increased aeolian input of terrestrial material during the last glacial (López-Martínez et al., 2006; Madureira et al., 1997).

On the longer term, several dust records from the eastern subtropical Atlantic indicate an increase in aeolian input during the intensification of the Northern Hemisphere glaciation (NHG) (e.g., deMenocal, 1995; Stein, 1985; Stein and Sarnthein, 1984; Tiedemann et al., 1994), which took place during the late Pliocene and marks the appearance of large continental ice sheets in the Northern Hemisphere. However, these records reflect changes in the African dust sources. Virtually nothing is known about variations in dust deposition in the northern North Atlantic and thus changes in North American dust sources over the course of the Plio-Pleistocene. This gap in understanding is significant given the facts that dust plays an important role in global climate and climate models show that incorporating the effect of dust on Northern Hemisphere ice sheets is crucial for simulating a complete glacial cycle (Ganopolski et al., 2010). Furthermore, changes in dust deposition over the Southern Ocean during the most recent glacial/interglacial cycles may have caused up to $40 \mathrm{ppmv}$ of the observed $90 \mathrm{ppm}$ change in atmospheric $\mathrm{CO}_{2}$ during the most recent glacial/interglacial cycles through its fertilizing effect on marine ecosystems (e.g., Kohfeld et al., 2005; Kumar et al., 1995; Martínez-Garcia et al., 2009; Watson et al., 2000). Moreover, long-term variations in Southern Ocean iron deposition may have played an important role in the Plio-Pleistocene intensification of Northern Hemisphere glaciations by promoting a strengthening of the global biological pump (Martínez-Garcia et al., 2011). In this context, determining the long-term evolution of dust accumulation in the northern North Atlantic is crucial to understand the mechanisms that drove Quaternary climate during the last $2.6 \mathrm{Ma}^{1}$

Using material from Integrated Ocean Drilling Project (IODP) Expedition 306 Site U1313, here we report the first orbitally-resolved long-term record of changes in aeolian input from the northern North Atlantic. We focus on the last 3.5 Ma to investigate whether changes in aeolian input were associated with the intensification of the NHG around $2.7 \mathrm{Ma}$ and/or the Mid-Pleistocene Transition (MPT) between 1.25 and $0.7 \mathrm{Ma}$ (Clark et al., 2006), two major steps in global climate toward more intense glacial conditions (e.g., Ruggieri et al., 2009).

\section{Regional settings}

Samples come from IODP Site U1313, located in the North Atlantic $\left(41.00^{\circ} \mathrm{N} ; 32.57^{\circ} \mathrm{W}\right)$, at the same latitude as the extensive loess deposits in the North American continent (Bettis et al., 2003). Site U1313 (3426 m water depth) is a re-drill of Deep Sea Drilling Project (DSDP) Leg 94 Site 607, which represents a benchmark site for Quaternary paleoceanography (e.g., Raymo et al., 1989; Ruddiman et al., 1989). The drilling of DSDP Site 607 in the 1980s preceded the advent of the shipboard capability for construction of composite sections and pass-through magnetometers for continuous measurement of magnetic parameters. With the re-drilling of Site 607, Site U1313 now provides the rare opportunity of a continuous high-resolution sediment record covering the complete period from the Pliocene to the Pleistocene at one of the most climatically sensitive locations in the world (Expedition 306 Scientists, 2006).

\footnotetext{
${ }^{1}$ Please note that we use the updated definitions of the Quaternary, Pliocene, and Pleistocene (Gibbard et al., 2009)
}

At present, surface ocean circulation in the mid-latitude North Atlantic is dominated by the Gulf Stream and North Atlantic Current (NAC) that transport oligotrophic and warm surface waters northward. The annual mean sea surface temperature (SST) at Site U1313 is $18.3^{\circ} \mathrm{C}$ (Locarnini et al., 2006). During glacials, however, surface ocean circulation in the North Atlantic was radically different as high-latitude waters migrated southward (e.g., Pflaumann et al., 2003) and massive armadas of ice-bergs episodically filled the North Atlantic north of $40^{\circ} \mathrm{N}$ (Ruddiman, 1977). Bottom waters in the North Atlantic basin nowadays are influenced by North Atlantic Deep Water (NADW). In contrast, during the most recent glacials poorly ventilated Antarctic Bottom Water (AABW) filled the deep North Atlantic basin ( $>2 \mathrm{~km}$ deep) and influenced the study site (Raymo et al., 1990, 1992) as deep water formation in the northern North Atlantic shifted southward (Rahmstorf, 2002).

With respect to atmospheric circulation, the westerlies are the dominant winds between 60 and $30^{\circ} \mathrm{N}$ during both boreal summer and winter, blowing from the high-pressure cell in the subtropics to the low-pressure cell associated to the atmospheric polar front. In general the westerlies are stronger during winter due to a deepening of the low-pressure cell (Fig. 1). Backward trajectories for both summer and winter clearly demonstrate that at present air masses from different altitudes over Site U1313 are transported by the westerlies and originate from the North American continent (Fig. 1). During glacials, and at specially the severe glacials that characterized the middle and late Pleistocene, the presence of large continental ice sheets (with a topography of up to several kilometers high) influenced atmospheric circulation (Pausata et al., 2011). Modeling studies depict that during the Last Glacial Maximum the westerlies were slightly more intense but remained the dominant winds over the North Atlantic (e.g., Hewitt et al., 2003; Pausata et al., 2011). Located at $41^{\circ} \mathrm{N}$ in the mid-latitude North Atlantic, Site U1313 was thus predominantly influenced during both glacials and interglacials by the westerlies that transport air masses from the North American continent over the North Atlantic.

\section{Sampling strategy Site U1313}

Four holes were drilled at Site U1313 from which two complete spliced stratigraphic sections for the Pleistocene were constructed by correlating physical properties between the holes (Expedition 306 Scientists, 2006). For this study, the correlation was further refined to ensure a complete and continuous stratigraphic section for Site U1313 covering the Pliocene and Pleistocene. In this process, the original meter composite depth (mcd)-scales from Holes U1313A, C, and D were updated by tying them to the mcd-scale for Hole U1313B, providing what we call an adjusted mcd (amcd)-scale (see Supplementary information). Creating a common depth scale allows data from different holes to be combined and compared and resolves conflicts in stratigraphic depth between holes that exist in the mcd scale. This amcd-scale was already used in several studies using material from Site U1313 (Ferretti et al., 2010; Naafs et al., 2010, 2011; Stein et al., 2009). Site U1313B was selected as the master hole because it is one of the deepest continuously cored holes and it is part of the primary splice that is being studied by many others. Because of this choice, amcd = mcd for Hole U1313B, with the mcd scales adjusted for the other three holes. The adjustments are based on simultaneously correlating the lightness $\left(\mathrm{L}^{*}\right)$, magnetic susceptibility $(\mathrm{X})$, and paleomagnetic data (inclination and intensity) between the four holes. These records were resampled every $1 \mathrm{~cm}$ down to $200 \mathrm{mcd}$ and correlated using the AnalySeries software (Paillard et al., 1996). Besides the upper $40 \mathrm{~cm}$, correlation between holes is consistently better than $\pm 5 \mathrm{~cm}$ down to 158 amcd ( $3.4 \mathrm{Ma}$ ), but becomes more uncertain further down section because of the lack of variations in physical properties. The tie-points for the new amcd-depths for all holes are given in the Supplementary information. 
a

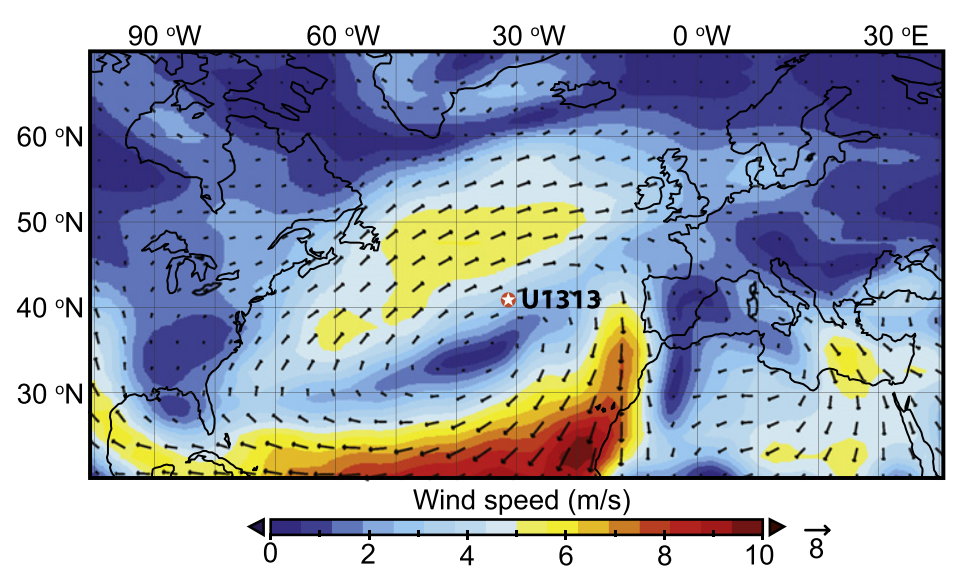

b

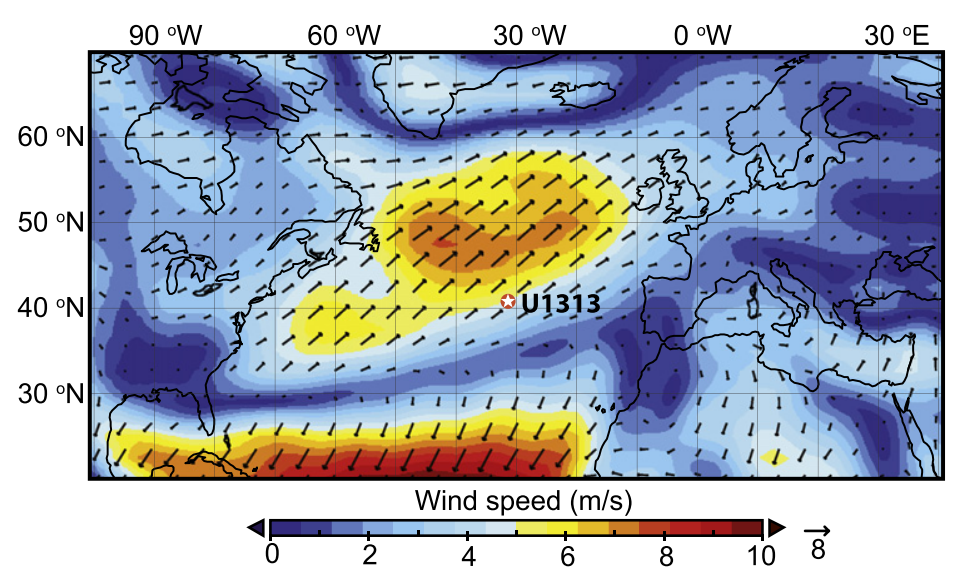

C 10-days backward trajectory July 20,2010

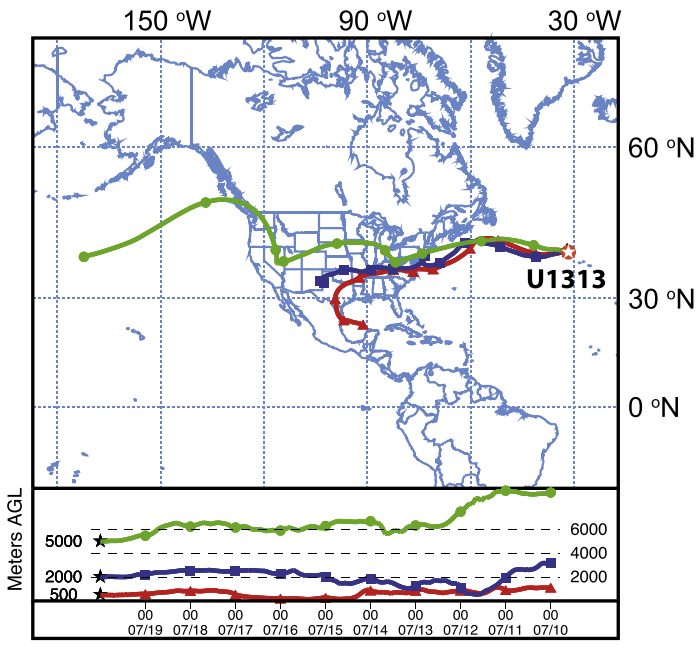

d

8-days backward trajectory Jan 14, 2010

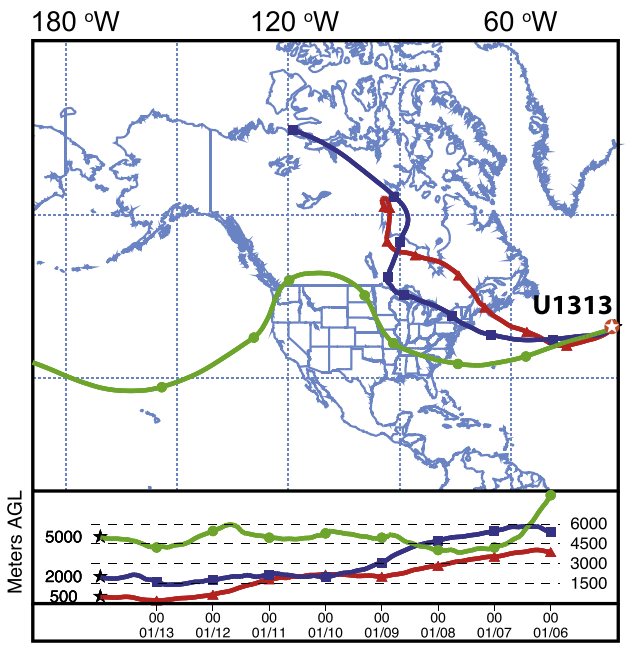

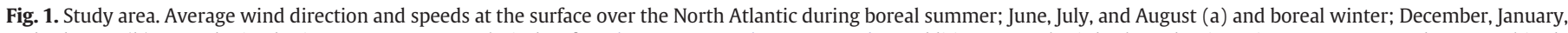

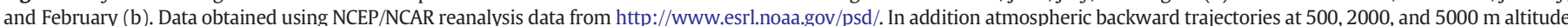
(typical for dust transport (Ben-Ami et al., 2009)) at Site U1313 during summer (c) and winter (d) are shown, calculated using HYSPLIT, available at http://www.arl.noaa.gov/.

In this study, samples from the primary splice, consisting of Holes U1313B and U1313C, were used. From the upper 160 amcd of Site U1313 (representing the last $3.5 \mathrm{Ma}$ ) samples of $10 \mathrm{~cm}^{3}$ were taken from the primary splice at a $20 \mathrm{~cm}$ interval, corresponding to a temporal resolution of $\pm 4 \mathrm{ka}$. A higher resolution (up to $2 \mathrm{~cm}$ in some parts, corresponding to a temporal resolution of $\pm 0.4 \mathrm{ka}$ ) was used for the last $1 \mathrm{Ma}$ (Marine Isotope Stage (MIS) 26-1) and between 2.78 and 2.65 Ma (MIS G9-G3). In total around 2540 samples were used in this study. All samples were freeze-dried after sampling and stored at $4{ }^{\circ} \mathrm{C}$ until further processing took place.

\section{Chronology}

For the largest part of the record (3.5-1 Ma) we used the shipboard age model (Expedition 306 Scientists, 2006), based on tuning of the lightness $\left(\mathrm{L}^{*}\right)$ from the primary splice to the global benthic foraminiferal $\delta^{18} \mathrm{O}$ stack (Lisiecki and Raymo, 2005). This method assumes that changes in lightness, caused by changing carbonate content due to variations in terrestrial input, mimicked changes in benthic foraminiferal $\delta^{18} \mathrm{O}$ without any temporal offset (Expedition 306 Scientists, 2006). For the late Pliocene and early Pleistocene this assumption holds and the shipboard age model is not significantly different from an age model based on benthic foraminiferal $\delta^{18} \mathrm{O}$ for the late Pliocene (Bolton et al., 2010) and is consistent with biostratigraphic and magnetostratigraphic datums (Expedition 306 Scientists, 2006; Sierro et al., 2009). However during the last $1 \mathrm{Ma}$, variations in surface water characteristics at Site U1313, hence lightness, occasionally lagged changes in benthic foraminiferal $\delta^{18} \mathrm{O}$ by several ka (Naafs et al., 2011). For the last 1 Ma a new age model was therefore constructed based on the combination of benthic foraminiferal $\delta^{18} \mathrm{O}$ and lightness that accurately captures the glacial terminations (Naafs et al., 2011). Even so, future high-resolution studies from Site U1313 using benthic foraminiferal $\delta^{18} \mathrm{O}$ combined with paleointensities will improve this age model. Based on our age model, the sedimentation rates over the whole record vary between 2 and $9 \mathrm{~cm} /$ ka (Fig. 3).

\section{Methodology}

\subsection{Accumulation rates of n-alkanes and n-alkan-1-ols}

The accumulation rates of the odd-carbon-numbered $\mathrm{C}_{27}-\mathrm{C}_{33}$ n-alkanes and $C_{26}$-alkan-1-ol at Site $\mathrm{U} 1313$ were used to reconstruct changes in aeolian input. Long-chain $n$-alkanes $\left(C_{21}-C_{33}\right)$ with a clear odd over even predominance and n-alkan-1-ols $\left(C_{22}-C_{32}\right)$ with a clear even over odd predominance are common constituents 
of the epicuticular waxes of terrestrial higher plants such as angiosperms and gymnosperms (e.g., Bianchi, 1995; Eglinton and Hamilton, 1967; see review in Diefendorf et al., 2011). They are a major component of modern dust even in remote ocean areas (Conte and Weber, 2002; Conte et al., 2003; Gagosian et al., 1981; Simoneit et al., 1977) as they can easily be removed from the leaf surface by wind or rain, especially by sandblasting during dust storms, or entrained as part of soil and transported over large distances. Numerous studies therefore used the accumulation of these lipids in distal marine sediments far from major fluvial inputs to infer changes in aeolian input to the open ocean (e.g., López-Martínez et al., 2006; Madureira et al., 1997; Martínez-Garcia et al., 2009, 2011). Indeed, several studies have shown that the concentrations and fluxes of these organic biomarkers agree well with those of independent inorganic tracers for windborne lithogenic material (e.g. ${ }^{233} \mathrm{Th}$, Fe, $\mathrm{Al}$, or Ti), suggesting that they can be used as faithful recorders of dust deposition in marine sediments (e.g., MartínezGarcia et al., 2009, 2011).

In order to differentiate odd numbered long-chain n-alkanes from higher plant material and the minor input of long-chain $n$-alkanes without odd over even predominance from other potential sources, we followed the approach developed by Villanueva et al. (1997). This approach assumes that the even-numbered long-chain $n$ alkanes $\left(C_{20}-C_{34}\right)$ in marine sediments reflect microbial input or reworking of odd-numbered $n$-alkanes and thus an equal amount of odd numbered long-chain $n$-alkanes does not originate from terrestrial higher plant material. This approach is supported by laboratory experiments that found an alteration in hydrocarbon composition and significant input of even-numbered long-chain $n$-alkanes due to bacterial re-working (Grimalt et al., 1988) as well as soil studies that indicate a decrease in $n$-alkane odd over even predominance with soil depth due to microbial reworking (Buggle et al., 2010). Therefore, the sum of the odd-numbered $C_{27}$ to $C_{33} n$-alkane homologues was corrected for the input of reworked $n$-alkanes by subtracting the sum of the even-numbered $C_{26}$ to $C_{34} n$-alkane homologues by using:

$A_{\text {plant }}=\sum_{i=0}^{2} C_{(27+2 i)}^{\text {odd }}-\sum_{i=0}^{2} C_{(28+2 i)}-1 / 2\left(C_{26}+C_{34}\right)$

(modified from Villanueva et al., 1997)

where $A_{\text {plant }}$ is the total amount of higher plant (non-reworked) $n$ alkanes for each sample in $\mathrm{ng} / \mathrm{g}$ and $\mathrm{C}_{26}-\mathrm{C}_{34}$ the abundance of the individual $n$-alkanes in $\mathrm{ng} / \mathrm{g}$. We must note that as higher plants to some extent also produce even-numbered long-chain $n$-alkanes (e.g., Chikaraishi and Naraoka, 2006), the resulting $A_{\text {plant }}$ record leads to an under estimation of the accumulation of higher plant material. We stress that the glacial increase in accumulation of odd-numbered long-chain $n$-alkanes starting in the late Pliocene $(2.7 \mathrm{Ma})$ is also evident in the non-corrected $n$-alkanes record (see Supplementary information) as well as in the record of the long-chain even $n$-alkan-1-ol, which is not corrected in any way.

The Carbon Preference Index (CPI), which is used to identify the input of terrestrial higher plant material, was calculated following Bray and Evans (1961):

$C P I=\frac{1}{2}\left[\left(\frac{C_{25}+C_{27}+C_{29}+C_{31}+C_{33}}{C_{24}+C_{26}+C_{28}+C_{30}+C_{32}}\right)+\left(\frac{C_{25}+C_{27}+C_{29}+C_{31}+C_{33}}{C_{26}+C_{28}+C_{30}+C_{32}+C_{34}}\right)\right]$

where $C_{24}-C_{34}$ indicates the concentration of the individual $n$-alkanes.

Mass accumulation rates of the biomarkers in $\mathrm{ng} / \mathrm{cm}^{2} / \mathrm{ka}$ were calculated using linear sedimentation rates, biomarker concentrations ( $A_{\text {plant }}$ for the $n$-alkanes), and dry bulk densities (DBD), calculated from shipboard measured wet bulk densities (WBD) using DBD $=-1.6047+$ 1.5805 WBD (Expedition 306 Scientists, 2006; Stein et al., 2009).

\section{2. $\delta^{13} \mathrm{C}$ of long-chain n-alkanes and n-alkan-1-ols}

Plants can photosynthesize in different ways. In general two types of photosynthetic pathways are distinguished, $C_{3}$ and $C_{4}$-plants, although a third type also exists (CAM-plants). $C_{3}$ plants (trees, shrubs, and cool-climate grasses) are the most abundant (95\% of total plants) and are the dominant species in forested regions and high latitude grasslands. $\mathrm{C}_{4}$ plants (notably tropical grasses) on the other hand have more efficient water use than $C_{3}$-plants because they can internally concentrate $\mathrm{CO}_{2}$ and are dominant in semi-arid regions. The different photosynthetic pathways of $C_{3}$ and $C_{4}$-plants results in an isotopic offset between the two (O'Leary, 1981). The compound specific stable carbon isotope ratio $\left({ }^{13} \mathrm{C}\right)$ of plant wax $n$-alkanes $\left(\mathrm{C}_{29}+\right.$ $C_{31}$ ) in $C_{3}$-plants is on average $-34.9 \%$, while for $C_{4}$-plants it is $-21.4 \%$ (Fig. 2 and references in caption). For the $n$-alkan-1-ols $\left(C_{26}+C_{28}\right)$ the values are $-33.5 \%$ and $-22.7 \%$ o, for $C_{3}$ and $C_{4}$-plants respectively (Fig. 2 and references in caption). Determining the $\delta^{13} \mathrm{C}$ value of $n$-alkanes, and to a lesser extent $n$-alkan-1-ols, accumulating in marine sediments is therefore a well-established proxy to distinguish between the input from $C_{3}$ and $C_{4}$-plants (e.g., Schefuss et al., 2003a; Tipple and Pagani, 2010) and infer information about the source of these lipids in marine sediments (López-Martínez et al., 2006).
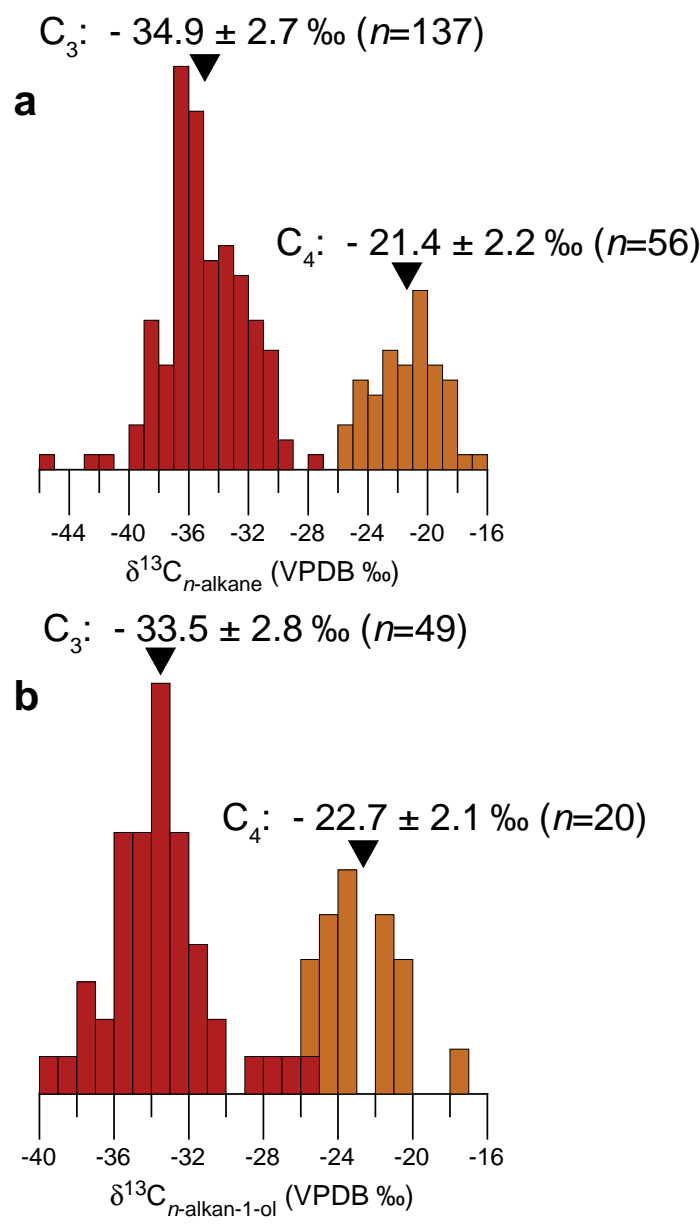

Fig. 2. Histograms of $\delta^{13} \mathrm{C}$ values in $n$-alkanes and $n$-alkan-1-ols. Compilation of all available literature $\delta^{13} \mathrm{C}$ values of modern plant wax $n$-alkanes $\left(C_{29}+C_{31}\right)$ a) and $n$ alkan-1-ols $\left(C_{26}+C_{28}\right)$ b) in $C_{3}$ (red) and $C_{4}$-plants (orange). (For interpretation of the references to color in this figure legend, the reader is referred to the web version of this article.)

Data compiled from Bi et al., 2005; Chikaraishi and Naraoka, 2003, 2006; Chikaraishi et al., 2004; Collister et al., 1994; Lockheart et al., 1997; Pedentchouk et al., 2008; Rieley et al., 1991; Rommerskirchen et al., 2006; Vogts et al., 2009. 


\subsection{Sea surface temperatures}

Annual mean SSTs $(0 \mathrm{~m})$ at Site U1313 were calculated using the modified alkenone unsaturation index $\left(U_{37}^{k^{\prime}}\right)$ and the global coretop calibration (Müller et al., 1998; Prahl and Wakeham, 1987).

\subsection{Spectral analysis}

The evolutionary spectra were computed using the short-time Fourier transform of overlapping segments with a 600,000-year Hamming window and 85\% overlap, following the approach of MartínezGarcia et al. (2010). All the records were detrended, linearly interpolated at 4 ka resolution and prewhitened before evolutionary spectral analysis. Prewhitening reduces the red spectral background noise arising from the nonlinear long-term evolution of climate records. Hence, it allows for a better resolution of the time series variability in the frequency range of obliquity (41 ka) and precession (23 and $19 \mathrm{ka}$ ), but it also attenuates some of the spectral power concentrated in lower frequencies ( $\geq 100 \mathrm{ka}$ ). Because high latitude dust deposition appears to be exponentially rather than linearly linked to climate (Lambert et al., 2008; Martínez-Garcia et al., 2009), in the case of the $n$-alkane records the logarithm of both concentrations and mass accumulation rates was used to compute the evolutionary spectra.

Phase and coherency estimates between the different time series were computed using the iterative spectral feature of the Arand software package (Howell et al., 2006) with a 500,000-year window and $1 / 2$ lags. All the records were detrended and resampled at $4 \mathrm{ka}$ resolution before cross-spectral analysis.

\section{Analytical techniques}

The biomarker records for Site U1313 were obtained using a gas chromatograph coupled to a LECO time of flight mass spectrometer (GC-TOF/MS). In total \pm 2540 samples from the primary splice of U1313 were measured for $U^{k^{\prime}}{ }_{37}$ ratios and long-chain $n$-alkane concentrations. Extraction and details of the analytical methods for the $U^{k^{\prime}}{ }_{37}$-based SSTs and long-chain $n$-alkane records are explained elsewhere (Hefter, 2008; Stein et al., 2009).

In 470 samples the concentration of the $C_{26}$-alkan-1-ol was measured. For this purpose the samples were derivatized with $\mathrm{N}, \mathrm{O}$ bis(trimethylsilyl) trifluoroacetamide $\left(200 \mu \mathrm{l}\right.$, heated for $2 \mathrm{~h}$ at $\left.60^{\circ} \mathrm{C}\right)$ shortly before analysis by GC/TOF-MS (using the same conditions as in Hefter, 2008). Concentrations of $C_{26}$-alkan-1-ol were determined from GC/TOF-MS peak areas (using $m / z$ of 75 ), whereby a compound specific response factor was obtained from the calibration with an external $\mathrm{C}_{26}$-alkan-1-ol standard (Fluka, Switzerland).

Compound specific $\delta^{13} \mathrm{C}$ values were determined in 12 samples at the University of Bristol using a GC-isotope ratio mass spectrometer (GC-IRMS). Because of the generally low concentration of higher plant biomarkers at Site U1313, relatively small sample size, and the current analytical limit for compound specific isotope analyses, it was not possible to obtain reliable $\delta^{13} \mathrm{C}$ values from more samples although we did attempt this.

GC-IRMS methods are identical to those used elsewhere (Handley et al., 2008). $\delta^{13} \mathrm{C}$ measurements were done in triplicate, and the $\delta^{13} \mathrm{C}$ value for the long-chain odd numbered $n$-alkanes was calculated by taking the weighted average of the $\delta^{13} \mathrm{C}$ value of the $C_{29}$ and $C_{31} n$ alkane. For the long-chain even numbered $n$-alkan-1-ols the weighted average of the $\delta^{13} \mathrm{C}$ value of the $C_{26}$ and $C_{28} n$-alkan-1-ol was taken. Compound specific $\delta^{13} \mathrm{C}$ values for the long-chain even numbered $n$-alkan-1-ols were then corrected for the derivatization process following Rieley (1994). Compound specific $\delta^{13} \mathrm{C}$ values were not corrected for variations in $\delta^{13} \mathrm{C}$ of atmospheric $\mathrm{CO}_{2}$ over time, because these were assumed to be small for the time scale used in this study (e.g., Seki et al., 2010). $\delta^{13} \mathrm{C}$ values are reported relative to the
Vienna Pee Dee Belemnite (VPDB)-scale, calculated by comparison against a calibrated reference $\mathrm{CO}_{2}$ gas.

\section{Results}

\subsection{Accumulation rates of n-alkanes and n-alkan-1-ols}

The results show that the accumulation rates of both the $C_{27}-C_{33}$ $n$-alkanes and $\mathrm{C}_{26}$-alkan-1-ol are low during most of the late Pliocene with values below 500 and $250 \mathrm{ng} / \mathrm{cm}^{2} / \mathrm{ka}$, respectively (Figs. 3 and 4 ). Values were slightly higher during glacials than during interglacials of the late Pliocene. The accumulation of terrestrial higher plant material increased significantly at Site U1313 during MIS G6 ( 2.7 Ma) (Fig. 4). Following MIS G6, every glacial is characterized by increased input of terrestrial higher plant material with maximum values of 2800 and $2100 \mathrm{ng} / \mathrm{cm}^{2} / \mathrm{ka}$ for the $n$-alkanes and $n$-alkan-1ol, respectively (Fig. 3). During interglacials, the accumulation rate of these terrestrial lipids is very low with values below $100 \mathrm{ng} / \mathrm{cm}^{2}$ / $\mathrm{ka}$. The glacial/interglacial variations of aeolian input can be seen in both the accumulation rates and the concentrations of long-chain odd numbered $n$-alkanes and long-chain even numbered $n$-alkan-1ol (Figs. 3 and 4). A period of relatively lower aeolian input occurred during glacials between 2.1 and 1.3 Ma.

\section{2. $\delta^{13} \mathrm{C}$ long-chain n-alkanes and n-alkan-1-ols}

Due to the low concentrations of higher plant waxes prior to 2.7 Ma and during interglacials, reliable $\delta^{13} \mathrm{C}$ values were obtained for selected glacials only [Fig. 3b,d]. $\delta{ }^{13} \mathrm{C}$ values of the long-chain $n$ alkanes and $n$-alkan-1-ols are relatively constant throughout the glacials of the last $2.7 \mathrm{Ma}$ with a value of around -31\%.

\subsection{Sea surface temperatures}

The SST record from Site U1313 demonstrates that surface waters in the mid-latitude North Atlantic were cooling during most of the early Pleistocene (Fig. 3), continuing the long-term trend that began in the late Pliocene (Naafs et al., 2010). During the Pliocene, SSTs were generally warmer than present, even during some glacials. Two major phases in the overall decrease of SSTs can be recognized; the late Pliocene (3.1-2.1 Ma) and early Pleistocene (1.5-0.3 Ma). Cooling was the most pronounced during glacials, especially during the last 1.5 Ma. Interglacial SSTs changed much less and present-day values were reached around $1 \mathrm{Ma}$. These results are almost identical to a lower resolution alkenone-based SST record from Site 607, of which U1313 is a re-drill, obtained using the traditional GC-FID method (Lawrence et al., 2010).

\section{Discussion}

\subsection{Source higher plant waxes}

Several lines of evidence indicate that both the odd-numbered $\mathrm{C}_{27}-\mathrm{C}_{33} n$-alkanes and $\mathrm{C}_{26}$-alkan-1-ol that accumulated at Site U1313 during glacials are derived from aeolian input of higher plant waxes originating from the North American continent. The close correlation between the abundance of the two compound classes (see Supplementary information) indicates a common origin, which is also supported by the similarity in $\delta^{13} \mathrm{C}$ values (Fig. 3). Fluvial input can be discarded as Site U1313 is located more than $1750 \mathrm{~km}$ from any continent.

A hypothetical contribution from old organic material to the $n$ alkane signal can be considered negligible because the concentrations and distribution of the plant lipid waxes are not correlated with the occurrence of the ice-rafting events of the last glacial cycle (Fig. 5). During the most recent glacial cycles the North Atlantic was 


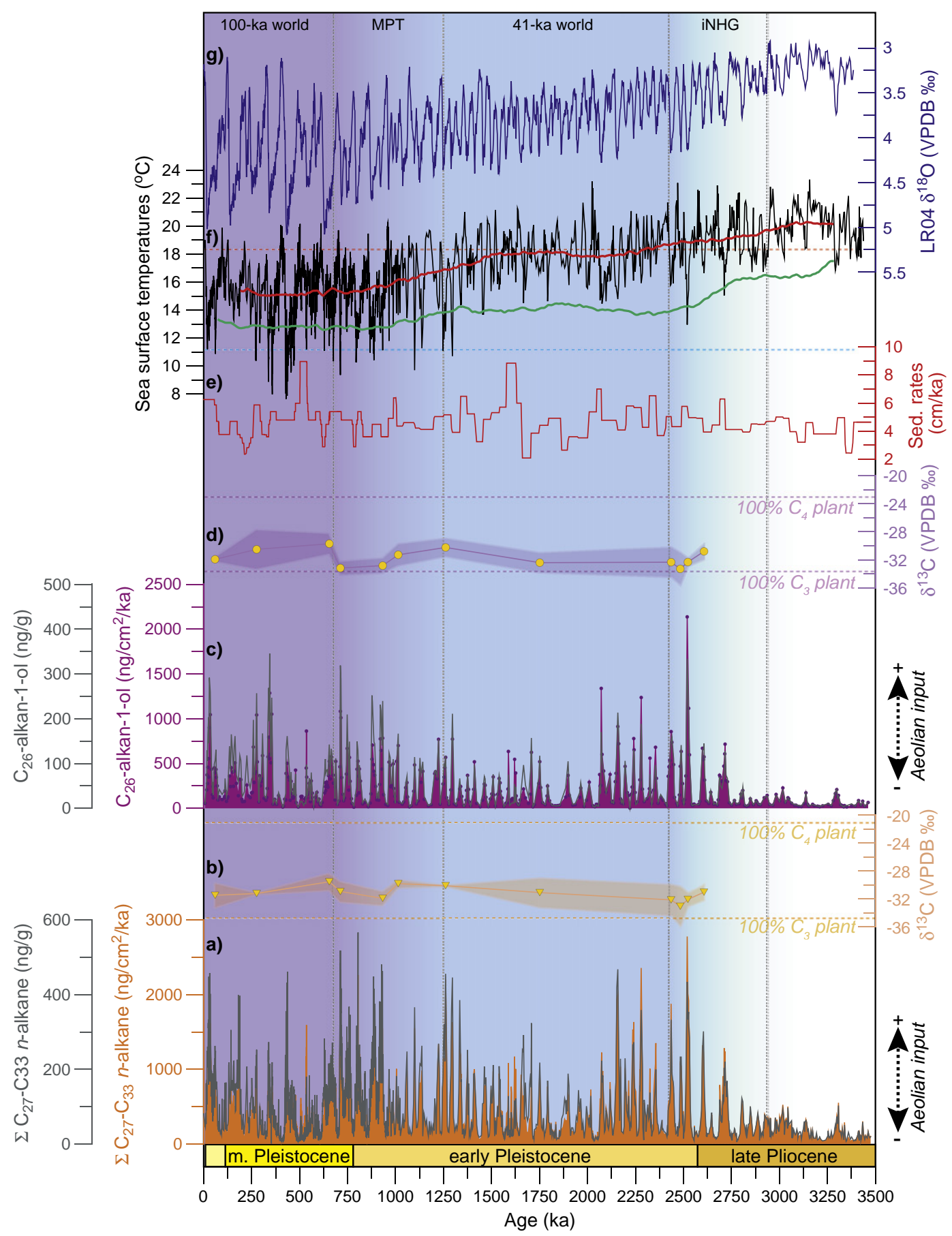

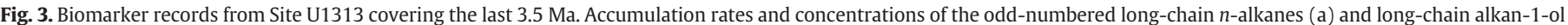

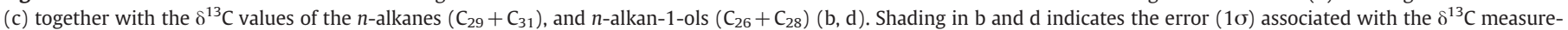

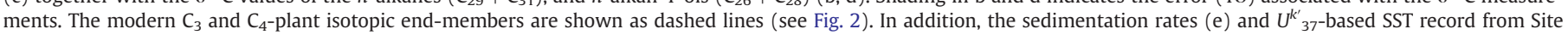

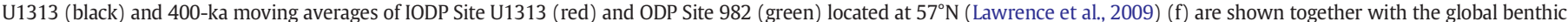

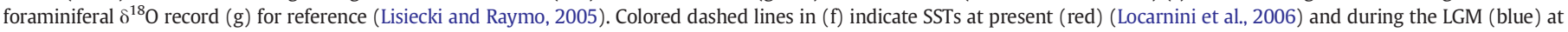

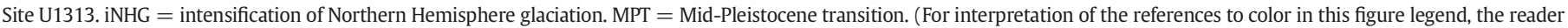
is referred to the web version of this article.)

characterized by episodes of massive ice-rafting (Heinrich) events originating from the circum-Atlantic ice sheets (Heinrich, 1988). As Site U1313 is located at the southern end of the ice-rafting debris (IRD)-belt (Ruddiman, 1977) it was also influenced by IRD-events during the Pleistocene (Naafs et al., 2011; Stein et al., 2009). IRD contains a wide-range of organic compounds (Rashid and Grosjean, 2006; Rosell-Melé et al., 1997) and could be a possible additional source of long-chain $n$-alkanes. However, in our record the accumulation rates of the odd-numbered long-chain $n$-alkanes and even-numbered long-chain $n$-alkan-1-ol are not correlated with the occurrence of the Heinrich Events of the last glacial cycle and associated input of ancient organic rich material (Fig. 5). This is similar to results from the northern North Atlantic, in the middle of the IRDbelt, where the abundance of long-chain $n$-alkanes and $n$-alkan1-ols during the last glacial is also not correlated with the occurrence of Heinrich Events (Madureira et al., 1997) and indicates that IRD is 


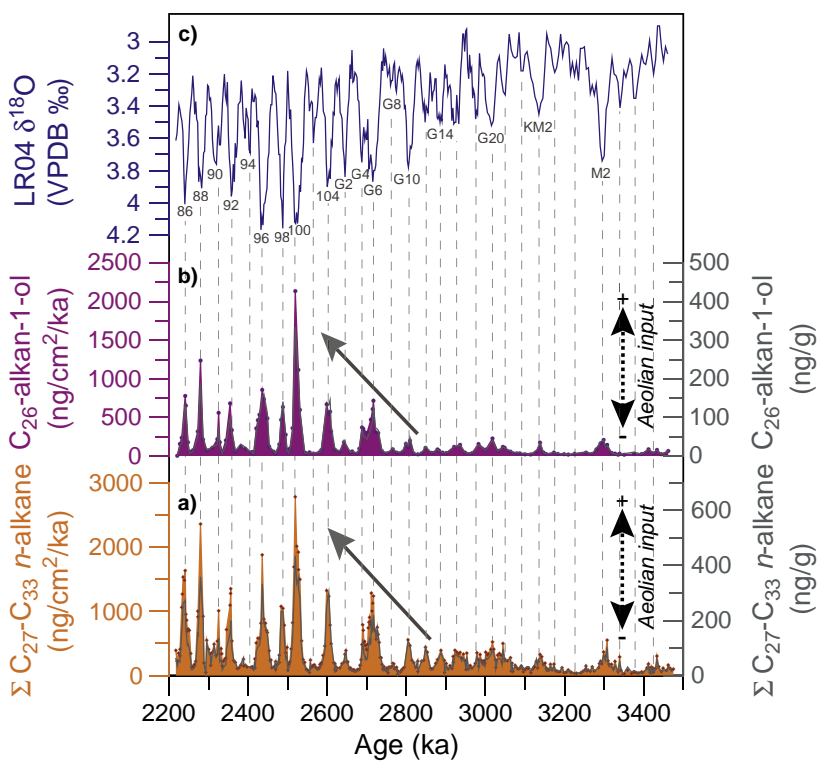

Fig. 4. Intensification of the Northern Hemisphere glaciation. Accumulation rates and concentrations of long-chain odd-numbered $n$-alkanes (a) and even-numbered alkan-1-ol (b) for the period between 3.5 and $2.2 \mathrm{Ma}$. For reference the global benthic foraminiferal $\delta{ }^{18} \mathrm{O}$ record (Lisiecki and Raymo, 2005) is plotted together with the marine isotope stage taxonomy $(\mathrm{c})$.

not a major source for the higher plant waxes. This is also supported by the carbon preference indices (CPI) of the $n$-alkanes, which vary between 2 and 6 for the last glacial cycle (Fig. 5). The $n$-alkane distribution of IRD derived organic material would be characteristic of a mature source and lead to a distribution of long-chain $n$-alkanes with a lower odd over even predominance $(\mathrm{CPI}<2.5$ ) (Bray and Evans, 1961). In addition, IRD for the first time started to influence the study area around 2.9 Ma (Kleiven et al., 2002), more than 200 ka before the increase in aeolian input at Site U1313. Following other studies from the North Atlantic (López-Martínez et al., 2006; Madureira et al., 1997), we thus conclude aeolian input of higher plant waxes to be the dominant source of the long-chain $n$-alkanes and $n$-alkan-1-ols at Site U1313.

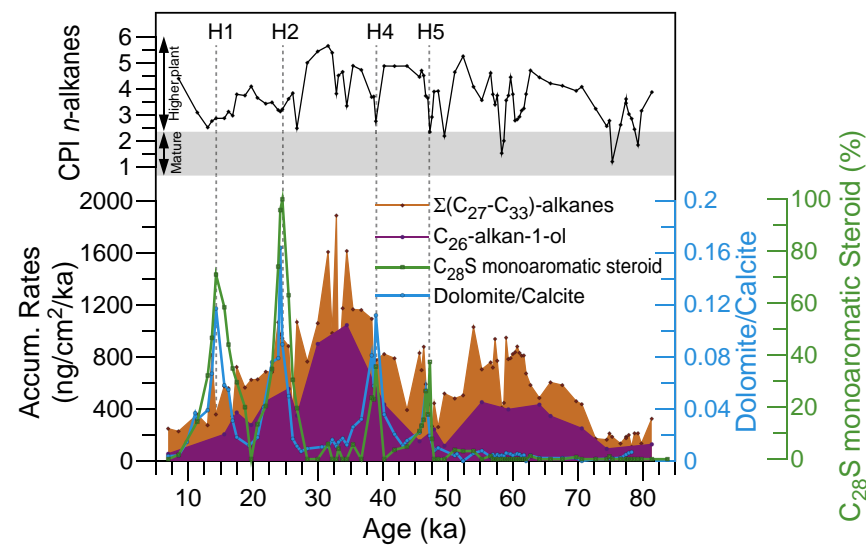

Fig. 5. The last glacial cycle. Accumulation rates of the of long-chain odd n-alkanes (orange) and even $n$-alkan-1-ol (purple) together with the abundance of dolomite (blue) and $\mathrm{C}_{28}(\mathrm{~S}) \mathrm{C}$-ring monoaromatic steroid (green) of the upper 5 adjusted meter composite depth (amcd) of IODP Site U1313, comprising the last $85 \mathrm{ka}$. The abundance of dolomite indicates the occurrence of IRD-events originating from the Laurentide ice sheet, while the abundance of $\mathrm{C}_{28}(\mathrm{~S})$ steroids indicates the input of ancient and organic rich material through ice-rafting (Naafs et al., 2011). In addition, the CPI for the $\left(C_{24}-C_{34}\right)$-alkanes (black) is shown. A CPI below 2.5 indicates the input from a mature source, while higher CPI values indicate higher plant waxes as source. H1-5 indicate the presence of Heinrich layers 1-5 (Naafs et al., 2011). (For interpretation of the references to color in this figure legend, the reader is referred to the web version of this article.)
Lastly, the CPI values, molecular distribution, as well as the $\delta^{13} \mathrm{C}$ values for the $n$-alkanes and $n$-alkan-1-ols are similar to those found at present in air masses originating from the North American continent (Conte and Weber, 2002; Conte et al., 2003) and significantly different from those found in dust originating from Northern Africa (Conte and Weber, 2002; Huang et al., 2000; Schefuss et al., 2003a), at present the largest source of dust in the world. In this regard, the most distinct features are the dominance of the $\mathrm{C}_{26}$-homologues in the $n$-alkan-1-ol and $n$-alkanoic acid molecular distributions (Fig. 6) and the depleted $\delta^{13} \mathrm{C}$ values for the $n$-alkanes and $n$-alkan-1-ols at Site U1313 (Fig. 7), which are typical for air masses origination from the North American continent and found for example in aerosol measurements at Bermuda (Conte and Weber, 2002). Air masses originating from Africa have different characteristics as the molecular distribution is typically dominated by higher mass homologues (e.g., $C_{28}$ and $C_{30}$ for the $n$-alkan-1-ol and $n$-alkanoic acid) (Conte and Weber, 2002) and the biomarker specific $\delta^{13} \mathrm{C}$ values are more enriched (Fig. 7).

The $\delta^{13} \mathrm{C}$ values found at Site U1313 during glacials are also similar to those found in lipids accumulating during the last glacial cycle close to the American continent (López-Martínez et al., 2006). Moreover, the relatively constant $\delta^{13} \mathrm{C}$ values over the last 2.7 Ma indicate a source that was continuously dominated by $\mathrm{C}_{3}$-plants (Fig. 3 ). In this context it is important to note the wide range of $\delta^{13} \mathrm{C}$ values in $\mathrm{C}_{3}$-plants (Fig. 2) and the indicated end-member value is only an average $\delta^{13} \mathrm{C}$ value for $C_{3}$-plants. A continuously dominant source of $C_{3^{-}}$ plants argues against both Africa and east Asia as main sources for the aeolian material at Site $\mathrm{U} 1313$ as in those regions $\mathrm{C}_{4}$-plants are more dominant and large variations in the dominant plant type, and hence $\delta^{13} \mathrm{C}$, took place during the Pliocene and Quaternary (e.g., Schefuss et al., 2003b; Yao et al., 2010; Zhisheng et al., 2005). Taken together, these results indicate that the terrestrial higher plant material accumulating at Site U13113 is of aeolian origin and originated from the North American continent, in line with the dominant westerly wind direction in the mid-latitude North Atlantic and the backward trajectories estimated for the core location (Fig. 1).

\subsection{Variations in aeolian input}

Visual comparison of the records of aeolian input from Site U1313 for the last $800 \mathrm{ka}$ to the dust flux in Antarctica (Lambert et al., 2008) reveals that the two are well correlated (Fig. 8). The latter has already been shown to be correlated with the aeolian flux in the low-latitudes (Winckler et al., 2008) and the Southern Ocean (Martínez-Garcia et al., 2009, 2011), aside from the differences in the magnitude of the glacial/interglacial change. In addition, although few marine records of dust input extend back to the Pliocene, those available indicate a similar shift toward more aeolian input that started during the intensification of the Northern Hemisphere Glaciation in (northwest) Africa (Dersch and Stein, 1991, 1994; Tiedemann et al., 1994) and the Southern Ocean (Martínez-Garcia et al., 2011). This also coincides with the onset of extensive loess deposition in northern China (Yang and Ding, 2010) and increased volcanic ash and dust deposition in the North Pacific (Bailey et al., 2011). These results thus suggest a regime shift in the late Pliocene to global synchronous strengthening of dust sources during glacials.

The reconstructed 30-fold increase in aeolian input of terrestrial higher plant waxes to the North Atlantic during glacials of the Quaternary is also similar to observations from the Antarctic ice cores where $\mathrm{a} \pm 25$-fold increase in dust flux over the last eight glacial cycles is inferred (Lambert et al., 2008). As Site U1313 is located in the middle of the North Atlantic it is likely that a large fraction of the aeolian material does not reach the study area and is deposited closer to the North American continent. Future long-term records that are taken from a position closer to the North American continent, therefore, will likely show even higher accumulation rates of terrestrial material during 

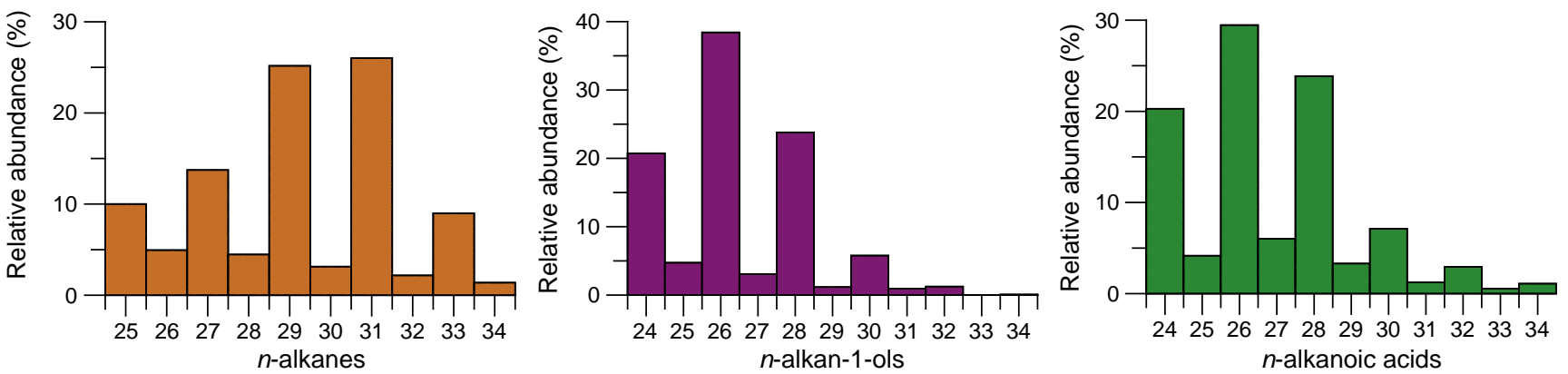

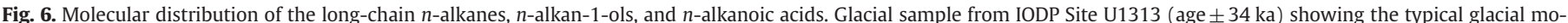

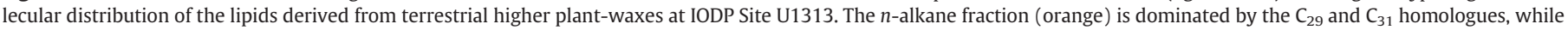

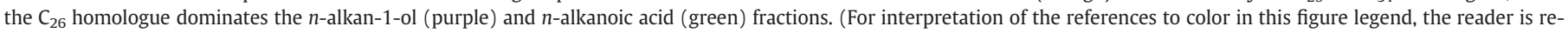
ferred to the web version of this article.)

the glacials of the Quaternary. In fact this is supported by the biomarker record from ODP Site 1060, located at Blake Outer Ridge close to the North American continent, where during the last glacial the accumulation of long-chain $n$-alkanes and $n$-alkan-1-ols was an order of magnitude higher relative to Site U1313 (López-Martínez et al., 2006).

Classically, increased accumulation of terrestrial material in marine sediments during glacials is thought to result from a combination of processes that involve the expansion of continental dust sources as a consequence of the increased glacial erosion and aridity, and a more efficient atmospheric transport of dust particles as a result of the reduced hydrological cycle, and increased wind intensity or gustiness during glacial stages (e.g., Mahowald et al., 2011; McGee et al., 2010; Yung et al., 1996). However, an overall increase in wind speed from the late Pliocene toward the present does not agree with modeling results that indicate stronger westerly winds during the late Pliocene warm period in the North Atlantic (Haywood et al., 2000), or at most only little changes in atmospheric circulation

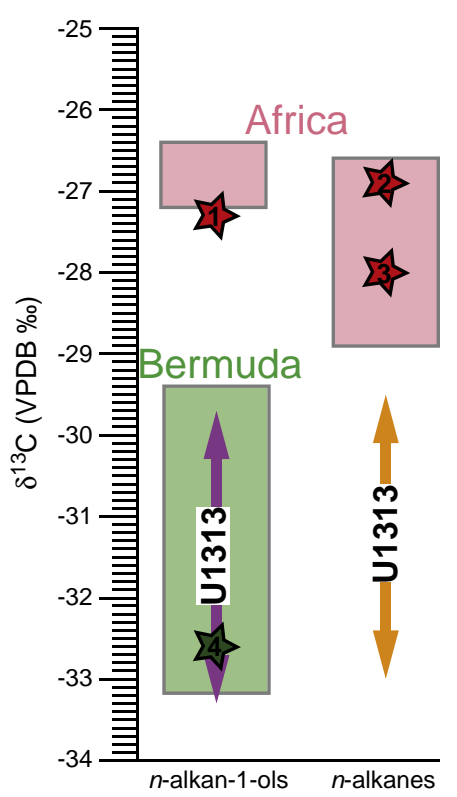

Fig. 7. $\delta^{13} \mathrm{C}$ as source indicator. Range of measured $\delta^{13} \mathrm{C}$ values at Site U1313 of the $n$ alkanes $\left(C_{29}+C_{31}\right)$, and $n$-alkan-1-ols $\left(C_{26}+C_{28}\right)$ (orange and purple arrow), together with the range of $\delta^{13} \mathrm{C}$ in these compounds in aerosol measurements from Bermuda (green box) and off the coast of Africa (pink box). In addition, average $\delta^{13} \mathrm{C}$ values for long-chain $n$-alkanes and $n$-alkan-1-ols in dust samples obtained off the coast of Africa (star 1-3) and from within the North American continent (star 4) are shown (Conte and Weber, 2002; Conte et al., 2003; Huang et al., 2000; Simoneit, 1997). (For interpretation of the references to color in this figure legend, the reader is referred to the web version of this article.) north of $\sim 40^{\circ} \mathrm{N}$ (Brierley et al., 2009). These model results also concur with surface ocean characteristics at Site U1313 that indicate more vigorous ocean circulation during the late Pliocene relative to the early Pleistocene (Naafs et al., 2010). An additional important consideration in this regard is that the westerlies respond mainly to changes in the thermal contrast in the middle of the atmosphere rather than to changes at the surface and the suggestion that glacials are associated with stronger winds is not supported by ocean circulation data (Toggweiler and Russell, 2008).

The 30-fold increase in aeolian input of terrestrial higher plant waxes as observed at Site U1313 relative to the 2-4-fold increase in dust deposition observed at low-latitudes (Winckler et al., 2008) indicates the presence of an amplifying mechanism in our record that is probably related to the presence of continental ice sheets in the source region. In addition, the strengthening of storm tracks directly south of the large continental ice sheets (Pollard and Thompson, 1997) may have also contributed to the increased aeolian input during glacials.

Modeling results for the Last Glacial Maximum (LGM) demonstrate that the margins of the North American ice sheets were important glaciogenic dust sources (Ganopolski et al., 2010). This is also supported by studies of loess deposits in North America, which demonstrate that during the LGM loess was deposited on a large scale south of the maximum extent of the Laurentide ice sheet (Bettis et al., 2003), and transported from the extensive glacial outwash plains by predominant (north)westerly winds (Muhs and Bettis, 2000). It is likely that the higher plant material that accumulated at Site U1313 during glacials is transported in a similar way. The amplifying effect of glacial erosion in the generation of dust has also been suggested to

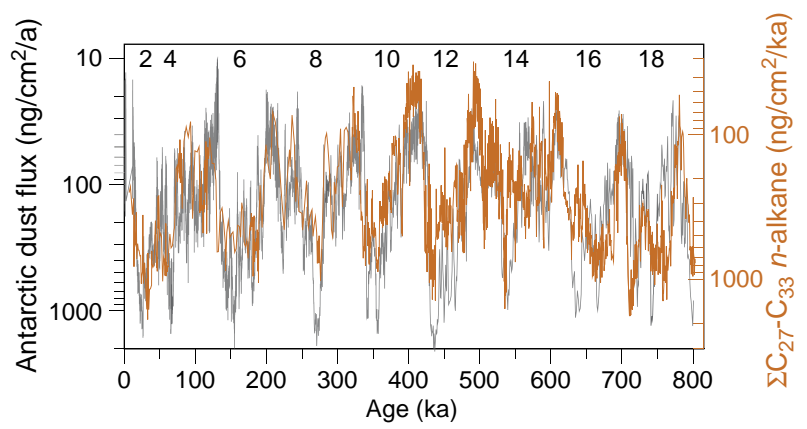

Fig. 8. Aeolian input at Site U1313 compared to dust flux in Antarctica. Abundance of long-chain odd-numbered $n$-alkanes at Site U1313 during the last $800 \mathrm{ka}$ (orange) plotted together with the dust flux in Antarctica (laser-scattering data, black) (Lambert et al., 2008). Both records are plotted using their own and independently obtained agemodels. Numbers on top indicate marine isotope stages associated to the different glacials. (For interpretation of the references to color in this figure legend, the reader is referred to the web version of this article.) 
explain the higher glacial/interglacial variability found in marine sediments from the Southern Ocean (Martínez-Garcia et al., 2009) relative to the low latitudes (Winckler et al., 2008). The 30 times increase in aeolian input of terrestrial higher plant waxes in our record indicates that this process of glacial erosion may have been more important than in high southern latitudes, where the dust deposition was only 5 to 8 times higher during glacials (Martínez-Garcia et al., 2009, 2011), and suggests that dust deposition in IODP Site U1313 mainly reflect changes in glaciogenic dust generation associated with the advance and retreat of North American ice-sheets.

The appearance of large continental ice sheets in the Northern Hemisphere (North America) at the end of the late Pliocene can be concluded from the widespread occurrence of IRD in sediments from both the North Atlantic and North Pacific during glacials starting at 2.7 Ma (Kleiven et al., 2002; Maslin et al., 1998; Shackleton et al., 1984 ), the presence of a glacial till at $39^{\circ} \mathrm{N}$ in the North America continent, dated to around 2.4 Ma (Balco and Rovey, 2010), and an increase in benthic foraminiferal $\delta^{18} \mathrm{O}$ values at $2.7 \mathrm{Ma}$ (Lisiecki and Raymo, 2005), modeled to reflect an increase in the volume of the North American and Eurasian ice sheets (Bintanja and van de Wal, 2008). This also coincides with the development of the subarctic Pacific halocline, which provided the moisture for the built-up of significant North American ice sheets starting at 2.7 Ma (Haug et al., 2005). We therefore argue that the sharp increase in glacial dust fluxes observed in our record at $2.7 \mathrm{Ma}$ is related to the strengthening of North American dust sources as a consequence of the appearance of large continental ice sheets and glacial outwash plains in North America. The period of relatively reduced aeolian input during glacials between $\sim 2.1$ and $1.3 \mathrm{Ma}$ roughly coincides with the absence of evidence for North American ice sheet advances south of $45-47^{\circ} \mathrm{N}$ (Balco and Rovey, 2010).

\subsection{Implications for the dynamics of the $\mathrm{NH}$ ice-sheets}

The Milankovitch theory, following the earlier work of Murphy (1869), predicts that variations in high-latitude summer solstice insolation were the primary forcing for the glacial/interglacial cycles of the Quaternary (Milankovitch, 1941). A major problem for this standard astronomical hypothesis is that high-latitude (e.g., $65^{\circ} \mathrm{N}$ ) summer (solstice) insolation is mainly driven by changes in precession, while proxy records indicative for early Pleistocene climate such as benthic foraminiferal $\delta^{18} \mathrm{O}$ (reflecting predominantly variations in continental ice volume) varied mainly at the obliquity period (Raymo and Nisancioglu, 2003; Ruddiman et al., 1986). To explain this mismatch, it has been proposed that precession related changes in ice volume in both Hemispheres did occur but cancel out in globally integrated proxies such as benthic foraminiferal $\delta^{18} \mathrm{O}$ (Raymo et al., 2006). Based on this hypothesis a simple ice sheet model that is sensitive to local (high-latitude) summer insolation was used to calculate Northern Hemisphere ice volume with a strong variance in the precession periods ( 23 and $19 \mathrm{ka}$ ) during the early Pleistocene (Raymo et al., 2006). However this hypothesis has been controversial, as direct evidence supporting precession related changes in Northern Hemisphere ice volume during the early Pleistocene is lacking. The hypothesis could potentially be tested if proxy data reflecting exclusively changes in Northern Hemisphere ice sheet dynamics were available and compared with the model output.

So far, it has been difficult to obtain long and continuous climate records indicative for Northern Hemisphere ice-sheet variability because ice sheet advances on a terrestrial margin are not recorded in most marine archives (e.g., IRD records), which demonstrate a strong 41-ka pacing (Raymo et al., 2006). As we argue that the record of aeolian input at Site U1313 is predominantly related to the dust production at active terrestrial glacial margins in North America, it provides a unique record to determine the astronomical pacing of the advance and retreat of the North American ice-sheet through the
Plio-Pleistocene and test the hypothesis that precession related changes in ice volume did occur in the Northern Hemisphere.

Although the lack of a continuous benthic foraminiferal $\delta^{18} \mathrm{O}$ record at Site U1313 during the Pleistocene prevents a detailed investigation of the evolution of the phasing between ice volume (benthic foraminiferal $\delta^{18} \mathrm{O}$ ) and aeolian input ( $n$-alkane record), a crossspectral analysis was computed for the late Pliocene where benthic foraminiferal $\delta^{18} \mathrm{O}$ data is available (Bolton et al., 2010). The results show that, taking into account the sampling resolution of around $4 \mathrm{ka}$, variations in aeolian input were in phase with changes in global ice volume at the obliquity (41 ka) band (Fig. 9). This is in-line with the suggestion of ice-sheet variability as the dominant control on changes in aeolian dust deposition at Site U1313. Therefore, evolutionary spectra of the $n$-alkane records were used to determine the dominant orbital control on North American ice-sheet dynamics and to test the hypothesis that significant precession related changes in ice volume in both Hemispheres did occur during the early Pleistocene.

If ice volume in the Northern Hemisphere during the early Pleistocene would vary according to precession as previously suggested (Raymo et al., 2006), the evolutionary spectra of the $n$-alkanes would be similar to that of the modeled Northern Hemisphere ice volume that assumes a strong variance in the precession periods. However, the evolutionary spectra of the $n$-alkane records and modeled Northern Hemisphere ice volume are radically different (compare Fig. 10c-d with Fig. 10f). The evolutionary spectrum of the modeled Northern Hemisphere ice volume is dominated by strong precession periods ( 23 and $19 \mathrm{ka}$ ). In contrast, the evolutionary spectra of the $n$-alkanes clearly demonstrate that during the early Pleistocene variance in the obliquity period (41 ka) dominates aeolian input at Site U1313 (Fig. 10c-d), similar to the benthic foraminiferal $\delta^{18} \mathrm{O}$ stack and SSTs at Site U1313 (Fig. 10a-b). Following the MPT, the frequencies shift toward the well documented dominance of $100 \mathrm{ka}$ cycles.

The absence of strong precession periods ( 23 and $19 \mathrm{ka}$ ) in the $n$ alkane records during the early Pleistocene suggest that the North American ice-sheet did not vary significantly as a response to precession during the early Pleistocene. These results are in good agreement with those obtained for our SST and two other high-latitude SST records that all depict a dominance of obliquity on high-latitude Northern Hemisphere climate during the early Pleistocene (e.g., Lawrence et al., 2009, 2010). Thus, according to these results it is unlikely that strong precession related changes in ice volume in the Northern Hemisphere did occur but cancel out in globally integrated proxies such as foraminiferal $\delta^{18} \mathrm{O}$. Other mechanisms are thus needed to explain the strong dominance of the obliquity period on climate during the early Pleistocene, possibly related to the role of integrated summer insolation in controlling the advance and retreat of Northern Hemisphere ice-sheets (Huybers, 2006).

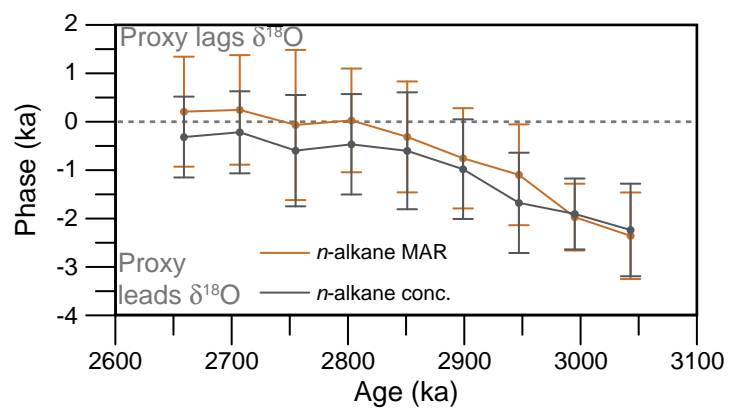

Fig. 9. Phasing. Phase and coherency of the $n$-alkane concentrations (gray) and mass accumulation rates (orange) relative to benthic foraminiferal $\delta^{18} \mathrm{O}$ at Site U1313 for the period between 3.1 and 2.6 Ma. (For interpretation of the references to color in this figure legend, the reader is referred to the web version of this article.) 


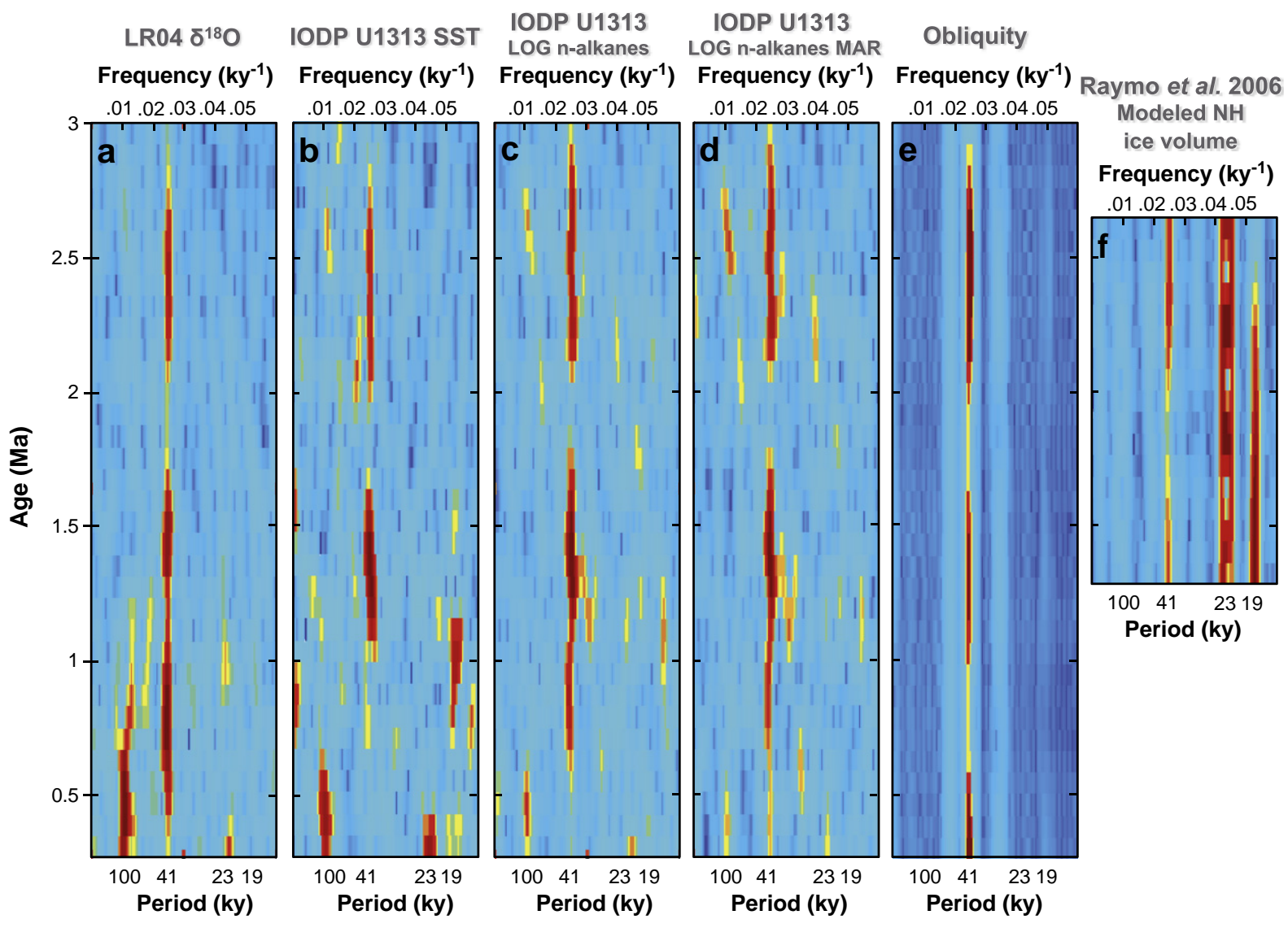

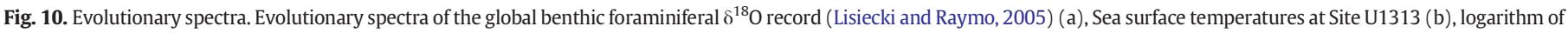

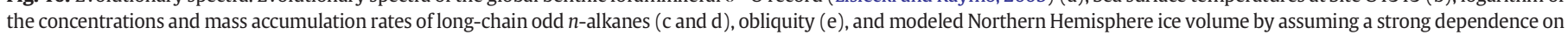
local summer insolation (Raymo et al., 2006) (f).

\section{Conclusion}

In summary, the flux of aeolian derived terrestrial higher plant waxes to the North Atlantic increased significantly during glacial stages starting at $2.7 \mathrm{Ma}$. The characteristics of the lipids of higher plant waxes (CPI and $\delta^{13} \mathrm{C}$ values) are similar as those found at present in air masses originating from North American continent and thus suggest this as main source for the aeolian material over the last 2.7 Ma. The timing of the onset of significant amounts of aeolian material accumulating in the North Atlantic coincides with the development of continental ice sheets at the North American continent. We argue that the episodic development of glacial outwash plains associated with large continental ice sheets in North America was the main cause of the observed increase in aeolian input during glacials from 2.7 Ma onwards. This is in line with the results of crossspectral analysis between benthic foraminiferal $\delta^{18} 0$ and $n$-alkane records from Site U1313, which indicate that variations in aeolian input are in phase with changes in ice volume at the obliquity band. Evolutional spectral analysis of the $n$-alkane records demonstrates that throughout the early Pleistocene, variance in the obliquity period (41 ka) dominates aeolian input and hence North American ice sheet dynamics. This argues against suggestions of precession-related variations in Northern Hemisphere ice volume during the early Pleistocene and urges for other mechanisms to explain the dominance of the obliquity period during the early Pleistocene.

So far the role of dust on long-term climate change has been largely neglected. Our results demonstrate that the increased dustiness that characterized the most recent glacial cycles has been a persistent feature of Quaternary climate. Future work should therefore focus on more precisely determining the effect of dust and associated feedback mechanisms on Quaternary climate.

Supplementary materials related to this article can be foundonline at doi:10.1016/j.epsl.2011.11.026

\section{Acknowledgments}

This research used samples and data provided by the Integrated Ocean Drilling Program. We would like to thank Robert Karandi and Walter Luttmer for technical support at the AWI-Bremerhaven. Cornelia Saukel is thanked for her help with the NCEP/NCAR reanalysis data. James Williams is acknowledged for his help with the compound specific stable isotope measurements at the University of Bristol. Antoni RoselMelé provided valuable comments on a preliminary version of this work. The core of this work has been funded by the Deutsche Forschungsgemeinschaft (DFG) through B.D.A.N. Additional support came from an ECORD Research Grant awarded to B.D.A.N and NSF-ODP Grant \#0549676 to G.A. We thank the editor Peter deMenocal for his help and four anonymous reviewers for their constructive comments. Data supplement is available online at http://doi.10.1594/PANGAEA. 757951.

\section{References}

Bailey, I., Liu, Q., Swann, G.E.A., Jiang, Z., Sun, Y., et al., 2011. Iron fertilisation and biogeochemical cycles in the sub-Arctic northwest Pacific during the late Pliocene intensification of Northern Hemisphere glaciation. Earth Planet. Sci. Lett. 307 (3-4), 253-265. doi:10.1016/j.epsl.2011.05.029.

Balco, G., Rovey, C.W., 2010. Absolute chronology for major Pleistocene advances of the Laurentide Ice Sheet. Geology 38 (9), 795-798. doi:10.1130/G30946.1. 
Ben-Ami, Y., Koren, I., Altaratz, O., 2009. Patterns of North African dust transport over the Atlantic: winter vs. summer, based on CALIPSO first year data. Atmos. Chem. Phys. 9 (20), 7867-7875. doi:10.5194/acp-9-7867-2009.

Bettis, A.E., Muhs, D.R., Roberts, H.M., Wintle, A.G., 2003. Last Glacial loess in the conterminous USA. Quat. Sci. Rev. 22 (18-19), 1907-1946. doi:10.1016/S0277-3791 (03)00169-0.

Bi, X., Sheng, G., Liu, X., Li, C., Fu, J., 2005. Molecular and carbon and hydrogen isotopic composition of $n$-alkanes in plant leaf waxes. Org. Geochem. 36 (10), 1405-1417. doi:10.1016/j.orggeochem.2005.06.001.

Bianchi, G., 1995. Plant waxes. In: Hamilton, R.J. (Ed.), Waxes: Chemistry. : Molecular Biology and Functions. The oily press, Dundee, pp. 175-222.

Bintanja, R., van de Wal, R.S.W., 2008. North American ice-sheet dynamics and the onset of 100,000-year glacial cycles. Nature 454 (7206), 869-872. doi:10.1038/ nature07158.

Bolton, C.T., Wilson, P.A., Bailey, I., Friedrich, O., Beer, C.J., et al., 2010. Millennial-scale climate variability in the subpolar North Atlantic Ocean during the late Pliocene. Paleoceanography 25, PA4218. doi:10.1029/2010PA001951.

Bray, E.E., Evans, E.D., 1961. Distribution of n-paraffins as a clue to recognition of source beds. Geochim. Cosmochim. Acta 22 (1), 2-15. doi:10.1016/0016-7037(61)90069-2.

Brierley, C.M., Fedorov, A.V., Liu, Z., Herbert, T.D., Lawrence, K.T., et al., 2009. Greatly expanded tropical warm pool and weakened Hadley circulation in the Early Pliocene. Science 323 (5922), 1714-1718. doi:10.1126/science.1167625.

Buggle, B., Wiesenberg, G.L.B., Glaser, B., 2010. Is there a possibility to correct fossil $n$-alkane data for postsedimentary alteration effects? Appl. Geochem. 25 (7), 947-957. doi:10.1016/j.apgeochem.2010.04.003.

Chikaraishi, Y., Naraoka, H., 2003. Compound-specific $\delta D-\delta 13 C$ analyses of $n$-alkanes extracted from terrestrial and aquatic plants. Phytochemistry 63 (3), 361-371. doi:10.1016/S0031-9422(02)00749-5.

Chikaraishi, Y., Naraoka, H., 2006. Carbon and hydrogen isotope variation of plant biomarkers in a plant-soil system. Chem. Geol. 231 (3), 190-202. doi:10.1016/ j.chemgeo.2006.01.026.

Chikaraishi, Y., Naraoka, H., Poulson, S.R., 2004. Carbon and hydrogen isotopic fractionation during lipid biosynthesis in a higher plant (Cryptomeria japonica). Phytochemistry 65 (3), 323-330. doi:10.1016/j.phytochem.2003.12.003.

Clark, P.U., Archer, D., Pollard, D., Blum, J.D., Rial, J.A., et al., 2006. The middle Pleistocene transition: characteristics, mechanisms, and implications for long-term changes in atmospheric $\mathrm{pCO}_{2}$. Quat. Sci. Rev. 25 (23-24), 3150-3184. doi:10.1016/j.quascirev.2006.07.008.

Collister, J.W., Rieley, G., Stern, B., Eglinton, G., Fry, B., 1994. Compound-specific [delta] 13C analyses of leaf lipids from plants with differing carbon dioxide metabolisms. Org. Geochem. 21 (6-7), 619-627. doi:10.1016/0146-6380(94)90008-6.

Conte, M.H., Weber, J.C., 2002. Long-range atmospheric transport of terrestrial biomarkers to the western North Atlantic. Global Biogeochem. Cycles 16 (4), 1142. doi:10.1029/2002gb001922.

Conte, M.H., Weber, J.C., Carlson, P.J., Flanagan, L.B., 2003. Molecular and carbon isotopic composition of leaf wax in vegetation and aerosols in a northern prairie ecosystem. Oecologia 135 (1), 67-77. doi:10.1007/s00442-002-1157-4.

deMenocal, P.B., 1995. Plio-Pleistocene African climate. Science 270 (5233), 53-59. doi:10.1126/science.270.5233.53.

Dersch, M., Stein, R., 1991. Paläoklima und paläoozeanische Verhältnisse im SW-Pazifik während der letzten 6 Millionen Jahre (DSDP-Site 594, Chatham Rücken, östlich Neuseeland). Geol. Rundsch. 80 (3), 535-556.

Dersch, M., Stein, R., 1994. Late Cenozoic records of eolian quartz flux in the Sea of Japan (ODP Leg 128, Sites 798 and 799) and paleoclimate in Asia. Palaeogeogr. Palaeoclimatol. Palaeoecol. 108 (3-4), 523-535. doi:10.1016/0031-0182(94)90250-X.

Diefendorf, A.F., Freeman, K.H., Wing, S.L., Graham, H.V., 2011. Production of n-alkyl lipids in living plants and implications for the geologic past. Geochimica et Cosmochimica Acta 75, 7472-7485. doi:10.1016/j.gca.2011.09.028.

Eglinton, G., Hamilton, R.J., 1967. Leaf epicuticular waxes. Science 156 (3780), 1322-1335. doi:10.1126/science.156.3780.1322.

Expedition 306 Scientists, 2006. Site U1313. In: Channell, J.E.T., Kanamatsu, T., Sato, T., Stein, R., Alvarez Zarikian, C.A., Malone, M.J., Scientists, E. (Eds.), Proceedings of Integrated Ocean Drilling Program. Integrated Ocean Drilling Program Management International, Inc, College Station TX.

Ferretti, P., Crowhurst, S.J., Hall, M.A., Cacho, I., 2010. North Atlantic millennial-scale climate variability 910 to $790 \mathrm{ka}$ and the role of the equatorial insolation forcing. Earth Planet. Sci. Lett. 293, 24-41. doi:10.1016/j.epsl.2010.02.016.

Fung, I.Y., Meyn, S.K., Tegen, I., Doney, S.C., John, J.G., et al., 2000. Iron supply and demand in the upper ocean. Global Biogeochem. Cycles 14 (1), 281-295. doi:10.1029/1999gb900059.

Gagosian, R.B., Peltzer, E.T., Zafiriou, O.C., 1981. Atmospheric transport of continentally derived lipids to the tropical North Pacific. Nature 291 (5813), 312-314. doi: $10.1038 / 291312 \mathrm{a} 0$.

Ganopolski, A., Calov, R., Claussen, M., 2010. Simulation of the last glacial cycle with a coupled climate ice-sheet model of intermediate complexity. Clim. Past 6 (2), 229-244. doi:10.5194/cp-6-229-2010.

Gibbard, P.L., Head, M.J., Walker, M.J.C., 2009. Formal ratification of the Quaternary System/Period and the Pleistocene Series/Epoch with a base at $2.58 \mathrm{Ma}$. J. Quat. Sci. 25 (2), 96-102. doi:10.1002/jqs.1338.

Grimalt, J.O., Torras, E., Albaigés, J., 1988. Bacterial reworking of sedimentary lipids during sample storage. Org. Geochem. 13 (4-6), 741-746. doi:10.1016/0146-6380 (88)90096-4.

Handley, L., Pearson, P.N., McMillan, I.K., Pancost, R.D., 2008. Large terrestrial and marine carbon and hydrogen isotope excursions in a new Paleocene/Eocene boundary section from Tanzania. Earth Planet. Sci. Lett. 275 (1-2), 17-25. doi:10.1016/ j.epsl.2008.07.030.
Haug, G.H., Ganopolski, A., Sigman, D.M., Rosell-Melé, A., Swann, G.E.A., et al., 2005 North Pacific seasonality and the glaciation of North America 2.7 million years ago. Nature 433 (7028), 821-825. doi:10.1038/nature03332.

Haywood, A.M., Sellwood, B.W., Valdes, P.J., 2000. Regional warming: Pliocene (3 Ma) paleoclimate of Europe and the Mediterranean. Geology 28 (12), 1063-1066. doi:10.1130/0091-7613.

Hefter, J., 2008. Analysis of alkenone unsaturation indices with fast gas chromatography/time-of-flight mass spectrometry. Anal. Chem. 80 (6), 2161-2170. doi:10.1021/ac702194m.

Heinrich, H., 1988. Origin and consequences of cyclic ice rafting in the Northeast Atlantic Ocean during the past 130,000 years. Quat. Res. 29 (2), 142-152. doi:10.1016 0033-5894(88)90057-9.

Hewitt, Hewitt, C., Stouffer, Stouffer, R., Broccoli, et al., 2003. The effect of ocean dynamics in a coupled GCM simulation of the Last Glacial Maximum. Clim. Dyn. 20 (2), 203-218.

Howell, P., Posies, N.J., Baughman, B.J., Ochs, L., 2006. ARAND Time Series Analysis Software. Brown University, Providence, RI

Huang, Y., Dupont, L., Sarnthein, M., Hayes, J.M., Eglinton, G., 2000. Mapping of C4 plant input from North West Africa into North East Atlantic sediments. Geochim. Cosmochim. Acta 64 (20), 3505-3513. doi:10.1016/S0016-7037(00)00445-2.

Huybers, P., 2006. Early Pleistocene glacial cycles and the integrated summer insolation forcing. Science 313 (5786), 508-511. doi:10.1126/science.1125249.

Kleiven, H.F., Jansen, E., Fronval, T., Smith, T.M., 2002. Intensification of Northern Hemisphere glaciations in the circum Atlantic region (3.5-2.4 Ma) - ice-rafted detritus evidence. Palaeogeogr. Palaeoclimatol. Palaeoecol. 184 (3-4), 213-223. doi:10.1016/S0031-0182(01)00407-2.

Kohfeld, K.E., Quéré, C.L., Harrison, S.P., Anderson, R.F., 2005. Role of marine biology in glacial-interglacial $\mathrm{CO}_{2}$ cycles. Science 308 (5718), 74-78. doi:10.1126/ science. 1105375.

Kumar, N., Anderson, R.F., Mortlock, R.A., Froelich, P.N., Kubik, P., et al., 1995. Increased biological productivity and export production in the glacial Southern Ocean. Nature 378 (6558), 675-680. doi:10.1038/378675a0.

Lambert, F., Delmonte, B., Petit, J.R., Bigler, M., Kaufmann, P.R., et al., 2008. Dust-climate couplings over the past 800,000 years from the EPICA Dome C ice core. Nature 452 (7187), 616-619. doi:10.1038/nature06763.

Lawrence, K.T., Herbert, T.D., Brown, C.M., Raymo, M.E., Haywood, A.M., 2009. Highamplitude variations in North Atlantic sea surface temperature during the early Pliocene warm period. Paleoceanography 24, PA2218. doi:10.1029/2008pa001669.

Lawrence, K.T., Sosdian, S., White, H.E., Rosenthal, Y., 2010. North Atlantic climate evolution through the Plio-Pleistocene climate transitions. Earth Planet. Sci. Lett. 300 (3-4), 329-342. doi:10.1016/j.epsl.2010.10.013.

Lisiecki, L.E., Raymo, M.E., 2005. A Pliocene-Pleistocene stack of 57 globally distributed benthic $\delta^{18} 0$ records. Paleoceanography 20, PA1003. doi:10.1029/2004PA001071.

Locarnini, R.A., Mishonov, A.V., Antonov, J.I., Boyer, T.P., Garcia, H.E., 2006. Volume 1: Temperature. In: Levitus, S. (Ed.), World Ocean Atlas 2005. U.S. Government Printing Office, Washington, D.C, p. 182.

Lockheart, M.J., Van Bergen, P.F., Evershed, R.P., 1997. Variations in the stable carbon isotope compositions of individual lipids from the leaves of modern angiosperms: implications for the study of higher land plant-derived sedimentary organic matter. Org. Geochem. 26 (1-2), 137-153. doi:10.1016/S0146-6380(96)00135-0.

López-Martínez, C., Grimalt, J.O., Hoogakker, B., Gruetzner, J., Vautravers, M.J., et al., 2006. Abrupt wind regime changes in the North Atlantic Ocean during the past 30,000-60,000 years. Paleoceanography 21, PA4215. doi:10.1029/2006PA001275.

Madureira, L.A.S., van Kreveld, S.A., Eglinton, G., Conte, M.H., Ganssen, G., et al., 1997. Late Quaternary high-resolution biomarker and other sedimentary climate proxies in a Northeast Atlantic core. Paleoceanography 12, 255-269. doi:10.1029/ 96 pa03120.

Maher, B.A., Prospero, J.M., Mackie, D., Gaiero, D., Hesse, P.P., et al., 2010. Global connections between aeolian dust, climate and ocean biogeochemistry at the present day and at the last glacial maximum. Earth Sci. Rev. 99 (1-2), 61-97. doi:10.1016/ j.earscirev.2009.12.001.

Mahowald, N.M., Kiehl, L.M., 2003. Mineral aerosol and cloud interactions. Geophys. Res. Lett. 30 (9), 1475. doi:10.1029/2002gl016762.

Mahowald, N.M., Yoshioka, M., Collins, W.D., Conley, A.J., Fillmore, D.W., et al., 2006a. Climate response and radiative forcing from mineral aerosols during the last glacia maximum, pre-industrial, current and doubled-carbon dioxide climates. Geophys. Res. Lett. 33 (20), L20705. doi:10.1029/2006gl026126.

Mahowald, N.M., Muhs, D.R., Levis, S., Rasch, P.J., Yoshioka, M., et al., 2006b. Change in atmospheric mineral aerosols in response to climate: last glacial period, preindustrial, modern, and doubled carbon dioxide climates. J. Geophys. Res. 111 (D10) D10202. doi:10.1029/2005jd006653.

Mahowald, N., Albani, S., Engelstaedter, S., Winckler, G., Goman, M., 2011. Model insight into glacial-interglacial paleodust records. Quat. Sci. Rev. 30 (7-8) 832-854. doi:10.1016/j.quascirev.2010.09.007.

Martin, J.H., 1990. Glacial-interglacial $\mathrm{CO}_{2}$ change: the iron hypothesis. Paleoceanography 5 (1), 1-13. doi:10.1029/PA005i001p00001.

Martínez-Garcia, A., Rosell-Melé, A., Geibert, W., Gersonde, R., Masqué, P., et al., 2009 Links between iron supply, marine productivity, sea surface temperature, and $\mathrm{CO}_{2}$ over the last $1.1 \mathrm{Ma}$. Paleoceanography 24 (1), PA1207. doi:10.1029/ 2008 pa001657.

Martínez-Garcia, A., Rosell-Melé, A., McClymont, E.L., Gersonde, R., Haug, G.H., 2010 Subpolar link to the emergence of the modern equatorial Pacific cold tongue. Science 328 (5985), 1550-1553. doi:10.1126/science.1184480.

Martínez-Garcia, A., Rosell-Melé, A., Jaccard, S.L., Geibert, W., Sigman, D.M., et al., 2011 Southern Ocean dust-climate coupling over the past four million years. Nature 476, 312-315. doi:10.1038/nature10310. 
Maslin, M.A., Li, X.S., Loutre, M.F., Berger, A., 1998. The contribution of orbital forcing to the progressive intensification of Northern Hemisphere glaciation. Quat. Sci. Rev. 17 (4-5), 411-426. doi:10.1016/S0277-3791(97)00047-4.

McGee, D., Broecker, W.S., Winckler, G., 2010. Gustiness: the driver of glacial dustiness? Quat. Sci. Rev. 29 (17-18), 2340-2350. doi:10.1016/j.quascirev.2010.06.009.

Milankovitch, M., 1941. Kanon der Erdbestrahlungen und seine Anwendung auf das Eiszeitenproblem Royal Serbian Academy, Belgrade.

Mills, M.M., Ridame, C., Davey, M., La Roche, J., Geider, R.J., 2004. Iron and phosphorus co-limit nitrogen fixation in the eastern tropical North Atlantic. Nature 429 (6989), 292-294. doi:10.1038/nature02550.

Muhs, D.R., Bettis, E.A., 2000. Geochemical variations in Peoria Loess of western Iowa indicate paleowinds of midcontinental North America during last glaciation. Quat. Res. 53 (1), 49-61. doi:10.1006/qres.1999.2090.

Müller, P.J., Kirst, G., Ruhland, G., von Storch, I., Rosell-Melé, A., 1998. Calibration of the alkenone paleotemperature index Uk'37 based on core-tops from the eastern South Atlantic and the global ocean $\left(60^{\circ} \mathrm{N}-60^{\circ} \mathrm{S}\right)$. Geochim. Cosmochim. Acta 62 (10), 1757-1772. doi:10.1016/S0016-7037(98)00097-0.

Murphy, J.J., 1869. On the nature and cause of the glacial climate. Q. J. Geol. Soc. 25 (1-2), 350-356. doi:10.1144/GSL.JGS.1869.025.01-02.63.

Naafs, B.D.A., Stein, R., Hefter, J., Khèlifi, N., De Schepper, S., et al., 2010. Late Pliocene changes in the North Atlantic current. Earth Planet. Sci. Lett. 298 (3-4), 434-442. doi:10.1016/j.epsl.2010.08.023.

Naafs, B.D.A., Hefter, J., Ferretti, P., Stein, R., Haug, G.H., 2011. Sea surface temperatures did not control the first occurrence of Hudson Strait Heinrich Events during MIS 16. Paleoceanography 26, PA4201. doi:10.1029/2011PA002135.

O'Leary, M.H., 1981. Carbon isotope fractionation in plants. Phytochemistry 20 (4), 553-567. doi:10.1016/0031-9422(81)85134-5

Paillard, D., Labeyrie, L., Yiou, P., 1996. Macintosh program performs time-series analysis. Eos Trans. Am. Geophys. Union 77 (39), 379. doi:10.1029/96E000259.

Pausata, F.S.R., Li, C., Wettstein, J.J., Kageyama, M., Nisancioglu, K.H., 2011. The key role of topography in altering North Atlantic atmospheric circulation during the las glacial period. Clim. Past 7 (4), 1089-1101. doi:10.5194/cp-7-1089-2011.

Pedentchouk, N., Sumner, W., Tipple, B., Pagani, M., 2008. $\delta^{13} \mathrm{C}$ and $\delta \mathrm{D}$ compositions of $n$-alkanes from modern angiosperms and conifers: an experimental set up in central Washington State, USA. Org. Geochem. 39 (8), 1066-1071. doi:10.1016/ j.orggeochem.2008.02.005.

Pflaumann, U., Sarnthein, M., Chapman, M., de Abreu, L., Funnell, B., et al., 2003. Glacia North Atlantic: sea-surface conditions reconstructed by GLAMAP 2000. Paleoceanography 18, 1065. doi:10.1029/2002PA000774.

Pollard, D., Thompson, S.L., 1997. Climate and ice-sheet mass balance at the Last Glacia Maximum from the GENESIS version 2 global climate model. Quat. Sci. Rev. 16 (8), 841-863. doi:10.1016/S0277-3791(96)00115-1.

Prahl, F.G., Wakeham, S.G., 1987. Calibration of unsaturation patterns in long-chain ketone compositions for palaeotemperature assessment. Nature 330 (6146), 367-369. doi:10.1038/330367a0

Rahmstorf, S., 2002. Ocean circulation and climate during the past 120,000 years. Nature 419 (6903), 207-214. doi:10.1038/nature01090.

Rashid, H., Grosjean, E., 2006. Detecting the source of Heinrich layers: an organic geochemical study. Paleoceanography 21 (3), PA3014. doi:10.1029/ 2005 pa001240.

Raymo, M.E., Nisancioglu, K., 2003. The 41 kyr world: Milankovitch's other unsolved mystery. Paleoceanography 18 (1), 1011. doi:10.1029/2002pa000791.

Raymo, M.E., Ruddiman, W.F., Backman, J., Clement, B.M., Martinson, D.G., 1989. Late Pliocene variation in Northern Hemisphere ice sheets and North Atlantic deep water circulation. Paleoceanography 4 (4), 413-446. doi:10.1029/PA004i004p00413.

Raymo, M.E., Ruddiman, W.F., Shackleton, N.J., Oppo, D.W., 1990. Evolution of AtlanticPacific [delta]13C gradients over the last 2.5 m.y. Earth Planet. Sci. Lett. 97 (3-4) 353-368. doi:10.1016/0012-821X(90)90051-X.

Raymo, M.E., Hodell, D., Jansen, E., 1992. Response of deep ocean circulation to initiation of Northern Hemisphere glaciation (3-2 Ma). Paleoceanography 7, 645-672. doi:10.1029/92pa01609.

Raymo, M.E., Lisiecki, L.E., Nisancioglu, K.H., 2006. Plio-Pleistocene ice volume, Antarctic climate, and the global $\delta 180$ record. Science 313 (5786), 492-495. doi:10.1126/ science.1123296.

Ridgwell, A.J., 2002. Dust in the Earth system: the biogeochemical linking of land, air and sea. Philos. Trans. R. Soc. London, Ser. A 360 (1801), 2905-2924. doi:10.1098 rsta.2002.1096.

Ridgwell, A.J., Watson, A.J., 2002. Feedback between aeolian dust, climate, and atmospheric $\mathrm{CO}_{2}$ in glacial time. Paleoceanography 17 (4), 1059. doi:10.1029/ $2001 \mathrm{pa} 000729$.

Rieley, G., 1994. Derivatization of organic compounds prior to gas chromatographiccombustion-isotope ratio mass spectrometric analysis: identification of isotope fractionation processes. Analyst 119 (5), 915-919. doi:10.1039/AN9941900915.

Rieley, G., Collier, R.J., Jones, D.M., Eglinton, G., Eakin, P.A., et al., 1991. Sources of sedimentary lipids deduced from stable carbon-isotope analyses of individual compounds. Nature 352 (6334), 425-427. doi:10.1038/352425a0.

Rommerskirchen, F., Plader, A., Eglinton, G., Chikaraishi, Y., Rullkötter, J., 2006. Chemotaxonomic significance of distribution and stable carbon isotopic composition of long-chain alkanes and alkan-1-ols in C4 grass waxes. Org. Geochem. 37 (10), 1303-1332. doi:10.1016/j.orggeochem.2005.12.013.

Rosell-Melé, A., Maslin, M.A., Maxwell, J.R., Schaeffer, P., 1997. Biomarker evidence for "Heinrich" events. Geochim. Cosmochim. Acta 61 (8), 1671-1678. doi:10.1016/ S0016-7037(97)00046-X

Ruddiman, W.F., 1977. Late Quaternary deposition of ice-rafted sand in the subpolar North Atlantic (lat $40^{\circ}$ to $65^{\circ} \mathrm{N}$ ). Geol. Soc. Am. Bull. 88 (12), 1813-1827.
Ruddiman, W.F., Raymo, M., McIntyre, A 1986. Matuyama 41,000-year cycles: North Atlantic Ocean and Northern Hemisphere ice sheets. Earth Planet. Sci. Lett. 80 (1-2), 117-129. doi:10.1016/0012-821x(86)90024-5.

Ruddiman, W.F., Raymo, M.E., Martinson, D.G., Clement, B.M., Backman, J., 1989. Pleistocene evolution: Northern Hemisphere ice sheets and North Atlantic Ocean. Paleoceanography 4, 353-412. doi:10.1029/PA004i004p00353.

Ruggieri, E., Herbert, T., Lawrence, K.T., Lawrence, C.E., 2009. Change point method for detecting regime shifts in paleoclimatic time series: application to d180 time series of the Plio-Pleistocene. Paleoceanography 24, PA1204. doi:10.1029/ 2007pa001568.

Schefuss, E., Ratmeyer, V., Stuut, J.-B.W., Jansen, J.H.F., Sinninghe Damsté, J.S., 2003a. Carbon isotope analyses of $n$-alkanes in dust from the lower atmosphere over the central eastern Atlantic. Geochim. Cosmochim. Acta 67 (10), 1757-1767. doi:10.1016/S0016-7037(02)01414-X.

Schefuss, E., Schouten, S., Jansen, J.H.F., Sinninghe Damsté, J.S., 2003b. African vegetation controlled by tropical sea surface temperatures in the mid-Pleistocene period. Nature 422 (6930), 418-421. doi:10.1038/nature01500.

Seki, O., Foster, G.L., Schmidt, D.N., Mackensen, A., Kawamura, K., et al., 2010. Alkenone and boron-based Pliocene $\mathrm{pCO}_{2}$ records. Earth Planet. Sci. Lett. 292 (1-2), 201-211. doi:10.1016/j.epsl.2010.01.037.

Shackleton, N.J., Backman, J., Zimmerman, H., Kent, D.V., Hall, M.A., et al., 1984. Oxygen isotope calibration of the onset of ice-rafting and history of glaciation in the North Atlantic region. Nature 307 (5952), 620-623. doi:10.1038/ 307620a0.

Sierro, F.J., Hernandez-Almeida, I., Alonso-Garcia, M., Flores, J.A., 2009. Data report: Pliocene-Pleistocene planktonic foraminifer bioevents at IODP Site U1313. In: Channell, J.E.T., Kanamatsu, T., Sato, T., Stein, R., Alvarez Zarikian, C.A., Malone, M.J., the Expedition 303/306 Scientists (Eds.), Proceedings of the Integrated Ocean Drilling Program, Volume 303/306. College Station, TX.

Simoneit, B.R.T., 1997. Compound-specific carbon isotope analyses of individual longchain alkanes and alkanoic acids in Harmattan aerosols. Atmos. Environ. 31 (15), 2225-2233. doi:10.1016/s1352-2310(97)00055-1.

Simoneit, B.R.T., Chester, R., Eglinton, G., 1977. Biogenic lipids in particulates from the lower atmosphere over the eastern Atlantic. Nature 267 (5613), 682-685.

Stein, R., 1985. Late neogene changes of paleoclimate and paleoproductivity off northwest africa (D.S.D.P. Site 397). Palaeogeogr. Palaeoclimatol. Palaeoecol. 49 (1-2), 47-59. doi:10.1016/0031-0182(85)90004-5.

Stein, R., Sarnthein, M., 1984. Late Neogene events of atmospheric and oceanic circulation offshore Northwest Africa: high-resolution record from deep-sea sediments. Palaeoecol. Afr. 16, 9-36.

Stein, R., Hefter, J., Grützner, J., Voelker, A., Naafs, B.D.A., 2009. Variability of surfacewater characteristics and Heinrich-like events in the Pleistocene mid-latitude North Atlantic Ocean: biomarker and XRD records from IODP Site U1313 (MIS 16-9). Paleoceanography 24, PA2203. doi:10.1029/2008PA001639.

Sugden, D.E., McCulloch, R.D., Bory, A.J.M., Hein, A.S., 2009. Influence of Patagonian glaciers on Antarctic dust deposition during the last glacial period. Nat. Geosci. 2 (4), 281-285. doi:10.1038/ngeo474.

Tiedemann, R., Sarnthein, M., Shackleton, N.J., 1994. Astronomic timescale for the Pliocene Atlantic $\delta^{18} \mathrm{O}$ and dust flux records of Ocean Drilling Program Site 659. Paleoceanography 9, 619-638. doi:10.1029/94pa00208.

Tipple, B.J., Pagani, M., 2010. A 35 Myr North American leaf-wax compound-specific carbon and hydrogen isotope record: implications for C4 grasslands and hydrologic cycle dynamics. Earth Planet. Sci. Lett. 299 (1-2), 250-262. doi:10.1016/ j.epsl.2010.09.006.

Toggweiler, J.R., Russell, J., 2008. Ocean circulation in a warming climate. Nature 451 (7176), 286-288

Villanueva, J., Grimalt, J.O., Cortijo, E, Vidal, L, Labeyriez, L, 1997. A biomarker approach to the organic matter deposited in the North Atlantic during the last climatic cycle. Geochim. Cosmochim. Acta 61 (21), 4633-4646. doi:10.1016/S0016-7037 (97)83123-7.

Vogts, A., Moossen, H., Rommerskirchen, F., Rullkötter, J., 2009. Distribution patterns and stable carbon isotopic composition of alkanes and alkan-1-ols from plant waxes of African rain forest and savanna C3 species. Org. Geochem. 40 (10), 1037-1054. doi:10.1016/j.orggeochem.2009.07.011.

Watson, A.J., Bakker, D.C.E., Ridgwell, A.J., Boyd, P.W., Law, C.S., 2000. Effect of iron supply on Southern Ocean $\mathrm{CO}_{2}$ uptake and implications for glacial atmospheric $\mathrm{CO}_{2}$. Nature 407 (6805), 730-733. doi:10.1038/35037561.

Winckler, G., Anderson, R.F., Fleisher, M.Q., McGee, D., Mahowald, N., 2008. Covariant glacial-interglacial dust fluxes in the equatorial Pacific and Antarctica. Science 320 (5872), 93-96. doi:10.1126/science.1150595.

Yang, S., Ding, Z., 2010. Drastic climatic shift at $~ 2.8 \mathrm{Ma}$ as recorded in eolian deposits of China and its implications for redefining the Pliocene-Pleistocene boundary. Quat. Int. 219 (1-2), 37-44. doi:10.1016/j.quaint.2009.10.029.

Yao, Z., Xiao, G., Wu, H., Liu, W., Chen, Y., 2010. Plio-Pleistocene vegetation changes in the North China Plain: magnetostratigraphy, oxygen and carbon isotopic composition of pedogenic carbonates. Palaeogeogr. Palaeoclimatol. Palaeoecol. 297 (2), 502-510. doi:10.1016/j.palaeo.2010.09.003.

Yung, Y.L., Lee, T., Wang, C.-H., Shieh, Y.-T., 1996. Dust: a diagnostic of the hydrologic cycle during the Last Glacial Maximum. Science 271 (5251), 962-963. doi:10.1126/science.271.5251.962

Zhisheng, A., Yongsong, H., Weiguo, L., Zhengtang, G., Clemens, S., et al., 2005. Multiple expansions of $\mathrm{C} 4$ plant biomass in East Asia since 7 Ma coupled with strengthened monsoon circulation. Geology 33 (9), 705-708. doi:10.1130/g21423.1. 